\title{
Merchant Guilds, Taxation and Social Capital*
}

\author{
Roberta Dessí $\quad$ Salvatore Piccolo
}

December 2, 2015

\begin{abstract}
We develop a theory of the emergence of merchant guilds as an efficient mechanism to foster cooperation between merchants and rulers, building on the complementarity between merchant guilds' ability to enforce monopoly over trade and their social capital. Unlike existing models, we focus on local merchant guilds, rather than alien guilds, accounting for the main observed features of their behavior, internal organization and relationship with rulers. Our model delivers novel predictions about the emergence, variation, functioning, and eventual decline of this highly successful historical form of network. Our theory reconciles previous explanations and the large body of historical evidence on medieval merchant guilds. In doing so, we also shed novel light on the role of the guilds' social capital, and its importance for taxation, welfare, and the development of towns and their government in medieval Europe.
\end{abstract}

\section{JEL Classification: L20, L43, N7, N8.}

Keywords: merchant guild, social capital, collusion, political economy, trade, taxation.

\footnotetext{
*For many helpful comments and discussions, we would like to thank Ran Abramitzky, Dirk Bergemann, Federico Boffa, Fabio Braggion, Emilio Calvano, Guido Friebel, Oscar Gelderblom, Avner Greif, Luigi Guiso, Denis Hilton, Dilip Mookherjee, Lyndon Moore, Sheilagh Ogilvie, Marco Pagano, Nicola Pavoni, Sven Rady, Fernando Vega Redondo, Giuseppe Russo, Klaus Schmidt, Joel Sobel, Giancarlo Spagnolo, Jean Tirole, two anonymous referees and an Associate Editor. We also thank participants in the CSEF-IGIER summer meeting and seminar participants in Florence (EUI). A preliminary version of this paper was titled "Two is company, N is a crowd? Merchant guilds and social capital".

${ }^{\dagger}$ Toulouse School of Economics and CEPR. Email: roberta.dessi@tse-fr.eu.

${ }^{\ddagger}$ Catholic University of Milan. Email: salvapiccolo@gmail.com.
} 


\section{Introduction}

Since the pioneering work by Greif et al. (1994), merchant guilds have attracted considerable attention by economists, and for good reason. This celebrated historical institution dominated trade for several centuries, and its development was inextricably linked with the growth of medieval towns and the rise of the merchant class. The merchant guild has also been viewed by many as a shining example of social capital — see, e.g., Putnam et al., (1993) — bringing major economic and social benefits, thereby suggesting a very valuable potential role for such social capital even in modern economies - see, e.g., Bardhan (1996), Dasgupta (2000), Raiser (2001) and Stiglitz (1999).

Is this positive view of merchant guilds justified? What role did the guilds' social capital play? What is the rationale for the way merchant guilds operated, and for their relationship with medieval rulers? We address these questions theoretically, and then confront our model's predictions with the available historical evidence. The objective is to shed new light on the reasons for the emergence, organization, functioning, and eventual decline of this highly successful historical form of network.

Our model presents a very different, although complementary, theory of the emergence and role of merchant guilds relative to the existing literature and in particular to Greif et al. (1994), who were the first to provide a formal model of merchant guilds. They developed a theory of alien merchant guilds - i.e., associations of alien merchants supported by the rulers of the polities in which they traded. Historically, though, most merchant guilds emerged as local merchant guilds - i.e., associations of local merchants that obtained recognition and privileges (including monopoly power over local trade) from their local rulers. Alien merchant guilds were typically formed by the members of local merchant guilds who were active in long-distance trade, and remained under the control and supervision of the guilds from the merchants' polities of origin. ${ }^{1}$ Moreover, only a subset of local merchant guilds went on to form such foreign 'branches', primarily in the main international trade centers. It is, therefore, of considerable interest to understand the economic rationale for the emergence of local merchant guilds, and the reasons why medieval rulers were willing to grant them recognition and privileges. ${ }^{2}$ This is all the more important as local merchants dominated medieval towns, many of which acquired considerable power and autonomy. Hence, studying the roots of merchants' organizations and their relationships with rulers is crucial in understanding the wider political economy forces that shaped the development of towns and states.

Medieval rulers did not possess a reliable civil service to collect taxes, and employed a variety

\footnotetext{
${ }^{1}$ See, for example, Dessí and Ogilvie (2004, pp.9-11); Ogilvie (2011, pp. 24-25, 202-205). This should not be taken to mean that only members of the local merchant guild of the polity of origin could be members of an alien merchant guild: associate membership was sometimes offered to merchants from different cities of origin, although this practice was typically limited to specific times and circumstances (Ogilvie, 2011, p. 108). Similarly, it should be clear that alien merchant guilds were also subject to some control and supervision by their host polities.

${ }^{2}$ For a rich and detailed informal account of merchant guilds, local and alien, see Ogilvie (2011). Our work and hers build to some extent on the extensive review of historical evidence presented in Dessí and Ogilvie (2004).
} 
of agents for this purpose. The taxation of trade was costly and inefficient, with many tolls levied in markets, as well as ports, river crossings, and other points of transit. We develop a repeated game between the ruler of a medieval polity and a large number of (local) merchants to show how merchant guilds emerged as a mechanism to foster cooperation between merchants and rulers, raising revenue for the latter more efficiently: merchant guilds were exempted from paying tolls, and made direct transfers to rulers. This apparently straightforward alternative to reliance on tax collectors was far from simple to implement. In order to raise enough revenue for rulers, guild members had to secure collusive profits from trade. We study the conditions under which such collusion could be sustained, and its implications.

Effective collusion required that only guild members be authorized to trade, hence the granting of exclusive trading rights by rulers to merchant guilds. But, these exclusive rights had to be enforced, and used profitably. We identify two main channels through which guilds' social capital affected the sustainability of collusion. When applied to groups or networks, such as merchant guilds, the notion of social capital ${ }^{3}$ typically refers to cohesion and trust among members, and to their resulting ability to enforce group norms and engage in effective collective action. In our model, social capital facilitates cooperation among guild members to achieve two important objectives: first, detecting and intervening to defeat attempts by non-members to undermine the guild's monopoly over trade; second, coordinating on profit-maximizing market strategies for the group, and appropriate punishments of any member who chooses to deviate. By reducing the cost of effective collusion, greater guild social capital tends to make granting recognition and privileges to guilds more attractive for the ruler. On the other hand, greater social capital within a guild also increases its bargaining power vis-à-vis the ruler (reflecting the greater degree of cohesion among guild members), allowing the guild to secure a part of the collusive profits it generates.

Our theory identifies a number of other important determinants, beyond the guild's social capital, of the ruler's choice between the merchant guild regime and the tax collector regime: these include the strength and uncertainty of consumer demand, the geographical and population characteristics of the polity, and the degree of patience of the merchants. The model therefore yields a rich set of empirical predictions: we confront these with the available historical evidence in Sections 5 and 6, where they help to shed light on the timing and variation of emergence of merchant guilds; on their organization, norms and behavior; on their relationship with rulers and their role in the development of medieval towns and their administration; and finally on their decline.

The welfare implications of merchant guilds are complex. Our model shows that only those with sufficient social capital would have been granted recognition and privileges by rulers, since

\footnotetext{
${ }^{3}$ For definitions see, among others, Bourdieu (1986); Coleman (1990); Dasgupta and Serageldin (2000); Glaeser, Laibson and Sacerdote (2002); Guiso, Sapienza and Zingales (2004); Lin (2001); Putnam (2000); Sobel (2002); Spagnolo (1999). It should be noted, though, that social capital in our analysis is modeled as an exogenous feature of a group (guild), since we are interested in how equilibrium choices by rulers vary when faced with merchant associations possessing different characteristics and different degrees of cohesion among members.
} 
they represented a less costly way of raising revenue than reliance on tax collectors. In this sense, merchant guilds represented an efficiency improvement relative to the taxation alternatives available at the time. From the perspective of consumers, we show that the merchant guild regime implied the same level of consumer prices as the tax collector regime, except when demand realizations were large enough to require guild members to coordinate on a price below the monopoly price: in this case, consumers were better off under the guild regime. These implications are favorable to merchant guilds. On the other hand, the guilds' social capital may also have had less favorable welfare implications. Our model highlights one of these: effective collusion implied an upper bound on guild membership, which in some circumstances involved membership restrictions and exclusion. At the same time, the guilds' social capital, by increasing their bargaining power, enabled them to secure a share of collusive profits (net of transfers to the ruler). This generated inequality within the merchant class, with guilded merchants earning much more than other merchants who were excluded from trade.

The remainder of the paper is organized as follows. Section 2 presents a short introduction to merchant guilds and to the medieval taxation of trade, which motivates our model. Section 3 sets out the baseline model. Section 4 studies taxation and trade, and the conditions to sustain collusion. The choice between the tax-collector regime and the guild regime is first analyzed in Section 5. This section also reviews the historical evidence on the model's predictions. We then extend the model in a variety of ways in Section 6, and discuss the evidence on the resulting additional implications. The final Section 7 compares our theory to alternative theories of the emergence of merchant guilds, and offers our concluding remarks. All proofs are in the Appendix.

\section{Motivating evidence}

This section briefly reviews the historical evidence on merchant guilds and on the taxation of trade in the Middle Ages, which motivates our model.

\subsection{Medieval merchant guilds}

Medieval merchant guilds were associations of merchants in a particular town or city. The merchants could be wholesale and retail sellers, and trade one or more types of good, including spices $^{4}$, wine, grain, timber, furs, herring, honey, textiles ${ }^{5}$, bullion, etc. Some guilds included members active in production as well as trade: historians often refer to these as craft guilds but the distinction is blurred, as noted by Epstein (1991, p. 130), "Within many craft guilds were rules on the conduct of retail trade and signs that some masters had transformed themselves

\footnotetext{
${ }^{4}$ According to Lopez and Raymond (2001, pp. 108-114), the term 'spices' came to include not only seasonings, perfumes, dyestuffs and medicinals, but also a much wider variety of goods. The list they present, from Pegolotti's manual of commercial practice dated between 1310 and 1340, includes obvious candidates such as anise, ginger, cinnamon, cloves, fennel, pepper and nutmeg, but also items as varied as asphalt, wax, glue, gum, indigo, ivory, lead, tin, rice, copper, coral, soap, sugar, sulphur, turpentine.

${ }^{5}$ Notably cotton, wool, and silk.
} 
into wealthy merchants... In a sense, all craftsmen selling to the public were merchants... a sharp line does not separate the craft and merchant guilds". For the purposes of our model, what matters is trade: thus our analysis applies mainly to 'merchant guilds' (whose members specialized in trade), but can also be applied to those 'craft guilds' whose members engaged significantly in retail trade, as well as different aspects of production. It does not, on the other hand, apply to craft guilds whose members specialized in production and sold their output to merchants (outside the guild). ${ }^{6}$

\subsubsection{Local merchant guilds}

Our model focuses mainly on local merchant guilds. Historically, most merchant guilds emerged as associations of local merchants. These local merchant guilds were ubiquitous in medieval Europe (in England alone, for example, there were over one hundred towns with a local merchant guild). ${ }^{7}$ Local merchant guilds were supported by their local rulers, who granted them official recognition and a variety of important privileges, including exclusive rights over local trade. ${ }^{8}$

These privileges were sometimes granted as part of charters given to towns, which also gave the towns a degree of political, administrative and financial autonomy. This was the case in England, where many such town charters contained "a clause similar to the following: We grant a Gild Merchant with a hanse and other customs belonging to the Gild, so that [or 'and that'] no one who is not of the Gild may merchandise in the said town, except with the consent of the burgesses..." (Gross, 1890, p. 8). Thus English local merchant guilds were granted the right to exclude any non-member from trade. In continental Europe, the granting of monopoly privileges to local merchant guilds was not always linked to the granting of greater political autonomy to towns. A good example is the guild of the mercatores aque ("water merchants") in Paris: in 1170, the French king, Philip Augustus, "granted them a virtual monopoly of the Seine traffic between the bridges of Paris and Mantes...they increasingly assumed the responsibilities of municipal government under Philip's grandson, Louis IX...The water merchants may be regarded as the embryo of the municipal government recognized later in the century." (Baldwin, 1986, p. 348). Yet under Philip Augustus, "Unlike those of most towns in the royal domain, the bourgeois of Paris were permitted no semblance of autonomy" (Baldwin, 1986, p. 349 and Luchaire, 1902, p. 239).

\footnotetext{
${ }^{6}$ Richardson (2001, pp. 233-234) contrasts three types of craft guilds. The first, 'manufacturing' guilds, produced consumer goods and "sold most of their merchandise to merchants who resold it". These are essentially guilds who specialized in production. The second type provided local services (e.g., innkeepers), while the third type provided victuals. Richardson (2004, p. 13) then argues that manufacturing guilds did not possess rights to be sole sellers. This is entirely consistent with our analysis, since rulers could extract surplus from trade by giving exclusive rights to merchants, in return for transfers.

${ }^{7}$ See Gross (1890, pp. 9-16), for a list of all those for which there is explicit documentary evidence, many dating back at least to the eleventh and twelfth centuries. The actual number is likely to have been even greater, implying that by the thirteenth century, local merchant guilds were "one of the most prevalent and characteristic features of English municipalities." (p. 22).

${ }^{8}$ See Bernard (1972, p. 304), Dilcher (1984, pp. 72-76), Ehbrecht (1985, pp. 430, 449), Fryde (1985, p. 220), Schütt (1980, p. 79). For reviews and discussions, see Dessí and Ogilvie (2004), Ogilvie (2011).
} 
The privileges granted to local merchant guilds in many medieval European cities meant that alien merchants could be either excluded from trade, or allowed to trade only subject to a number of restrictions clearly intended to favor local merchants. ${ }^{9}$ Among the most common of these restrictions were "staple" rights and brokerage rights. Local guilds" "rights of staple" meant that alien merchants had to bring their merchandise to municipal warehouses where members of the local merchant guild could buy them at favorable prices. ${ }^{10}$ Local guilds' brokerage rights meant that alien merchants could not trade directly with consumers or with other alien merchants: they had to use members of the local merchant guild as intermediaries (brokers). ${ }^{11}$ Local merchant guilds also restricted access to towns: "Outsiders might enter and leave the town for purposes of wholesale trading only and for only a limited number of days, varying from place to place to between 14 and 40". ${ }^{12}$ At the same time, local merchant guilds could exclude from trade local individuals who were not members of the guild. ${ }^{13}$ In some cases, they could also benefit from market regulations that gave them a large competitive advantage relative to local producers. ${ }^{14}$

\subsubsection{Alien merchant guilds}

Some local merchant guilds established foreign branches ("colonies"15 and "consulates") ${ }^{16}$ in important trade centers, when a significant number of their members engaged in long-distance trade (many did not). These alien merchant guilds ${ }^{17}$ were closely linked to the local merchant guilds of their polities of origin: for example, merchants from a given town or city typically had to be members of the local merchant guild in their town or city in order to become members of any of its branches in other towns or cities, and being expelled from the local guild of their town or city of origin also entailed exclusion from all the alien merchant guilds linked to it. ${ }^{18}$

\footnotetext{
${ }^{9}$ See Hibbert (1963, pp. 169-74), Irsigler (1985, p. 59), Leguay (2000, p. 121), Planitz (1940, p. 25), Postan (1973, pp. 189-91), Reyerson (2000, pp. 59-60), Schultze (1908, pp. 498-502, 506, 523, 526-7), Spufford (2000, p. 177).

${ }^{10}$ Bernard (1972, p. 302); Kuske (1939).

${ }^{11}$ Bernard (1972, p. 302), Choroskevic (1996, pp. 84-6), Hibbert (1963, p. 170), Schultze (1908, pp. 498-502, 506, 523, 526-7), Spufford (2000, p. 177).

${ }^{12}$ Fryde (1985, p. 220).

${ }^{13}$ Fryde (1985, p. 220), Planitz (1940, pp. 25-8), Postan (1973, pp. 189-91); Schütt (1980, p. 121, pp. 398-9), Schulze (1985), Woodward (2003, p. 3).

${ }^{14}$ See, for example, Boldorf (2009, p.180).

${ }^{15}$ The term 'merchant colonies' is also used to refer to merchant communities in the early modern period (see, for example, Zakharov, Harlaftis and Katsiardi-Hering, 2012). Our focus is on the medieval period.

${ }^{16}$ See Dessí and Ogilvie (2004, p. 9), Ogilvie (2011, p. 94).

${ }^{17}$ For an analysis of a broader set of mercantile communities, including some with shared cultural beliefs but no formal organization, see Gelderblom and Grafe (2010).

${ }^{18}$ Ogilvie (2011, pp. 108, 112).
} 


\subsection{Medieval taxation of trade}

The use of tolls or customs to tax trade in Europe can be traced back to the Roman imperial custom system. ${ }^{19}$ This included taxes on sales transactions and taxes on goods in transit. $A d$ valorem tax rates typically varied between $2 \%$ and $5 \%$; there were also some fixed payments. Toll stations were situated at appropriate locations in the customs territories. Customs were collected thanks to close cooperation between civil administration and the army.

From at least the third century onwards, foreign merchants were subject to tight controls. In the Byzantine customs system, from the sixth century onwards, agents referred to as comerciarii were responsible for the apotheke ('customs houses' or 'commercial hostels'), where imported goods were bought and sold, and taxes collected. Official seals were attached to merchandise to prove that the appropriate tax had been paid. Under Charlemagne, trade was restricted to specific public markets, active at particular times and locations (legitimus mercatus): royal officials collected tolls from participating merchants.

In the post-Carolingian Middle Ages, when central authority was weakened and power dispersed, we nevertheless find many of the same basic features of trade taxation. Throughout medieval Europe, rulers tried to restrict trade to public markets, including a multitude of official fairs ${ }^{20}$, to ensure taxes could be collected. ${ }^{21}$ Tolls (customs, duties, subsidies) were collected at coastal ports as well as river and road toll stations, and mountain passes. ${ }^{22}$

\section{The baseline model}

This section introduces our model. Consider a medieval polity with three types of risk-neutral players: a ruler, $N$ identical merchants, and a tax-collector. ${ }^{23}$

The market. Merchants sell a homogeneous good whose unit cost is normalized to zero and compete to attract a single representative consumer. In every trading period $\tau \in[1, . .,+\infty)$ they quote prices. The consumer purchases one unit of the product. His utility from consumption is

$$
u\left(v^{\tau}, p^{\tau}\right)=v^{\tau}-p^{\tau}
$$

when (in period $\tau$ ) he buys at price $p^{\tau}$, and zero otherwise (we use the superscript $\tau$ to indicate time). The willingness to pay for the product $v^{\tau}$ is a random variable identically and indepen-

\footnotetext{
${ }^{19}$ Our brief review of the early medieval taxation of trade, including its Roman background, draws substantially on Middleton (2005).

${ }^{20}$ Probably the most famous example of medieval fairs is that of the Champagne fairs, but of course there were very many other fairs and markets, including numerous local ones accommodating primarily local trade.

${ }^{21}$ See, for example, Dijkman (2011, pp. 46-47), and Middleton (2005, p. 320).

${ }^{22}$ See Middleton (2005) and Ormrod (1999, p. 32). For a broader review of medieval taxation (not focusing specifically on trade), see Bonney (1999).

${ }^{23}$ We explicitly focus on risk-neutral parties in order not to rely on risk-sharing mechanisms that have been already analyzed in the network literature applied to economic history — see, e.g., Abramitzky (2008). We discuss the relationship between our model and this literature in Section 6 .
} 
dently distributed over time: for simplicity, it is equal to $\Delta>0$ with probability $\alpha$ and to 0 otherwise.

The ruler. The ruler governs the polity: he provides certain public goods, such as law enforcement and defence, and finances these with various sources of revenue, including the taxation of trade. He also spends on activities that provide him with private benefits, such as military campaigns and court display. ${ }^{24}$ For our purposes it is sufficient to treat his expenditures and his other sources of revenue as given exogenously, and to focus on the revenue he can raise from the taxation of trade. The ruler is assumed to maximize this revenue. This is a reasonable assumption for the historical period under consideration, when rulers typically attached a low weight to the well-being of ordinary consumers. ${ }^{25}$

To maximize his revenue from local trade, the ruler has two options. First, he can employ a tax collector (see the discussion of tolls in Section 2). Second, he can grant recognition and exclusive rights over trade to a merchant guild, in return for an appropriate transfer. These are essentially, from a fiscal perspective, two alternative taxation regimes. Let us consider each regime in turn, starting with the second option.

The guild. If the ruler chooses to grant recognition to a merchant guild, he endows it with privileges, notably the power to exclude individual merchants from trade (see the discussion of merchant guilds' exclusive rights in Section 2). However, the exercise of this power is not costless. Specifically, there are two kinds of duty that guild members must perform in order to enforce the guild's monopoly over trade and earn monopoly profits. First, when the guild has size $n<N$, insiders must exclude outsiders from trade. We assume that this exclusion effort requires a total per-period investment equal to $x(N-n)$, which is shared equally among guild members. This cost obviously increases with the number of outsiders to be excluded. It represents the cost of monitoring to detect any attempts by non-members to undermine the guild's monopoly, and intervening to ensure the attempts are not successful. Greater cohesion and trust among guild members (i.e., greater social capital) will reduce this cost, making it easier to cooperate, communicate and avoid free-riding problems. In the baseline model we assume that effective exclusion is only possible if every member contributes - i.e., pays the individual cost $x(N-n) / n$ : then outsiders are unable to trade. Otherwise, outsiders can successfully undercut the price that the guild members have agreed to charge. In the extensions to the baseline model we show that our results continue to hold when we assume a different monitoring technology, in which limited free-riding is less harmful.

The second type of duty required for the guild to operate successfully is an internal organization and coordination effort. This entails a total per-period cost $(n-1) f$, which captures the investment guild members must collectively sustain to coordinate successfully their actions i.e., the cost of defining and agreeing on their common market (pricing) strategy, of designing

\footnotetext{
${ }^{24}$ For historical evidence on the importance of these see, e.g., Brewer (1989).

${ }^{25}$ See, e.g., Bisson (2009, pp. 352-355).
} 
guild rules including a punishment code, of exchanging information, etc. ${ }^{26}$ We can think of this to some extent as a time cost: guild members had to participate in collective activities, such as meetings, social and religious gatherings, elections of guild officers, admission of new members, and so on. Importantly, the disutility of spending time on these collective activities will be lower in groups that have greater social capital, interpreted here as greater cohesion, closer ties, and more congruent preferences. Moreover, more social capital within a guild will also make coordination easier through greater trust and easier reliance on shared information. We will return to this interpretation of $f$ as reflecting social capital below.

When the ruler grants recognition and privileges to a merchant guild, he requires an ex ante fee $R^{G}$, which is shared equally among the guild's members. ${ }^{27}$ This fee is set at the level which solves a standard Nash-bargaining problem between the ruler and the guild with weights $\beta$ and $1-\beta$, respectively. ${ }^{28}$

The tax-collector. In the absence of merchant organizations, the ruler delegates trade taxation to an agent: the tax-collector. Specifically, he endows the agent with the right to collect taxes on trade in the polity, in return for an ex ante royalty fee $R^{T}$. This is essentially 'tax farming', a very widespread practice in medieval Europe — see, e.g., Lyon and Verhulst (1967), Webber and Wildavsky (1986), Johnson and Koyama (2014). In every period, the tax-collector chooses a tax $t^{\tau}$ that merchants have to pay on each unit of product they sell. The tax revenue that he can levy is $t^{\tau}$ as long as trade occurs. Collecting taxes is costly, and the cost increases with the revenue to be raised: for example, more time needs to be spent at public markets and toll stations (see the discussion of medieval trade taxation in Section 2). We model this by assuming that in every trading period $\tau$ the tax collector pays a cost $c\left(t^{\tau}\right)=\psi t^{\tau}$, with $\psi \in[0,1]$, which is increasing in the revenue $t^{\tau}$ that can be extracted from the merchants.

\footnotetext{
${ }^{26}$ The importance of sharing information and designing guild rules, including possible sanctions, aimed at maximizing guild members' collective profits can be readily appreciated from the following examples. In Silesia, the rules for the town linen markets were designed to give guilded merchants a competitive advantage relative to producers (weavers): "The market regulations... restricted the time for purchasing to a few hours. When the striking of the clock opened the market in midmorning, hundreds of weavers rushed to the central market square. The houses of the wealthiest merchants were situated around the square, where they sat in front of their houses on high chairs overlooking the crowd. The sellers came to the foot of the chairs to offer their pieces. From above, the merchant checked the piece with a short glance and gave their price. If the weaver agreed, a chalk mark was made on the linen... the weavers had little chance to get a good deal given the level of activity on the market square. They flocked to the merchants' chairs by the dozen and had to accept the prices offered quickly. By agreement within the guild, no merchant was allowed to make an offer for a piece once it was signed with chalk. As the chalk mark could only be removed by washing the cloth, which was impossible given the restricted market time, once a piece was marked, the weaver could not invite alternative offers from other merchants. Postponing the sale of a piece for a week was usually impossible because the weavers very often lived from hand to mouth and were unable to store their linen. Thus, the guild members prevented competition within their ranks" (Boldorf, 2009, p.180). The next example highlights the importance of information and punishments: in English towns, alien merchants coming to trade "were carefully watched, lest they should sell or buy under colour or cover of a faithless gild brother's freedom, the latter being expelled from the fraternity or otherwise severely punished if found guilty of this offence" (Gross, 1890, p. 48).

${ }^{27}$ As will be discussed in the next section, guild members typically paid some entry fees, as well as a variety of other dues. The guild then made transfers to the ruler.

${ }^{28}$ Greater cohesion among guild members (more social capital) will increase their ability to bargain successfully with the ruler, increasing their share of collusive profits via a lower $\beta$.
} 
Payments to rulers and commitment. We assume that the ruler can commit to the chosen taxation regime at $\tau=0$, so that in both regimes payments to rulers take the simple form of a single ex-ante fee. This makes it possible to identify clearly some of the key trade-offs between recognizing a guild and relying on a tax collector, abstracting from commitment problems. We discuss the implications of imperfect commitment in the section on extensions to the baseline model.

Timing and strategies. At time $\tau=0$ the ruler decides whether to grant recognition to a merchant guild or hire an agent as tax-collector. In every trading period $\tau \geq 1$ the game proceeds as follows:

- Demand is realized;

- Merchants quote prices;

- Trade takes place.

There is perfect monitoring: if a guild member deviates by undercutting in any period, the other members observe the identity of the deviating "brother" by the end of that period. This assumption seems reasonable in the case of medieval polities. Indeed, as discussed in Section 2, most of the trading activities at that time were taking place in public markets where merchants could easily monitor each other's pricing strategy.

All agents have a common discount factor $\delta \in[0,1)$. The equilibrium concept is subgame perfect Nash equilibria (SPNE). Finally, in the baseline model we assume that

$$
\Delta \geq(N-1) \max \left\{x, \frac{f}{\alpha}\right\}
$$

This assumption simply allows for the possibility of a single-member guild - i.e., the revenue that can be obtained from trade is greater than the cost of excluding all but one merchant - and a guild that includes every merchant in the polity - the (expected) revenue is greater than the operating costs when all merchants are admitted to membership of the guild. In the extensions to the baseline model and in the Appendix we will relax this hypothesis.

\section{The basic trade-off facing revenue-maximizing rulers}

We begin by characterizing the profit that the ruler can achieve when merchants are not organized in a guild, and then proceed to examine the role of guilds.

\subsection{Trade and taxation in the absence of merchant guilds}

Suppose that the ruler hires an agent entitled to impose taxation and collect the corresponding revenue. The tax rate is chosen to maximize the revenue from taxation. We will solve the game 
using a backward-induction logic. Assume that $t^{\tau} \geq 0$ is the per-unit tax that merchants have to pay in period $\tau$. In that period merchant $i$ earns a profit equal to

$$
\pi_{i}^{\tau}\left(\mathbf{p}^{\tau}\right)=D_{i}^{\tau}\left(\mathbf{p}^{\tau}\right)\left(p_{i}^{\tau}-t^{\tau}\right)
$$

where $\mathbf{p}^{\tau} \equiv\left(p_{1}^{\tau}, . ., p_{N}^{\tau}\right) \in \Re_{+}^{N}$ is the vector of prices quoted by the $N$ competing merchants in period $\tau$. Merchant- $i$ 's individual demand is

$$
D_{i}^{\tau}\left(\mathbf{p}^{\tau}\right) \equiv\left\{\begin{array}{ll}
0 & \Leftrightarrow p_{i}^{\tau}>\min \left\{\mathbf{p}^{\tau}\right\} \\
\frac{1}{\#\left\{j: p_{j}=\min \{\mathbf{p}\}\right\}} & \Leftrightarrow p_{i}^{\tau}=\min \left\{\mathbf{p}^{\tau}\right\}
\end{array},\right.
$$

which is equal to $\frac{1}{M}$ if $M \leq N$ merchants (including $i$ ) quote the lowest market price and thus share the consumer's demand uniformly, and is equal to zero otherwise (we use the subscript $i$ to indicate merchants). ${ }^{29}$

The tax collector will optimally set $t^{\tau}=\Delta$ in every trading period in which $v^{\tau}=\Delta$ and $t^{\tau}=0$ otherwise, so as to implement the monopoly outcome. In fact, he has no incentive to choose $t^{\tau}$ lower than $\Delta$, because this would extract less than the monopoly profit. In addition, setting $t^{\tau}$ higher than $\Delta$ would also not be profitable because $\Delta$ is the maximal profit that merchants can (collectively) repay in every trading period. Hence, the tax collector's (expected) intertemporal profit is

$$
V^{T}=\frac{\alpha \Delta(1-\psi)}{1-\delta} \geq 0
$$

which is increasing in the consumer's expected willingness to pay $\alpha \Delta$, and decreasing in the cost of collecting taxes $\psi$. The ruler fully extracts this surplus by setting $R^{T}=V^{T}$.

\subsection{Merchant guilds: trade, taxation and privileges}

Suppose now that $n \leq N$ merchants organize themselves as a group able to act in their collective interest: the guild. The ruler grants privileges to them and, in particular, monopoly power over trade - i.e., only members of the guild are officially authorized to trade. Under what conditions can the guild implement a better outcome than the tax collector, from the ruler's point of view?

To answer this question we must first examine how the viability of effective collusion among guild members, yielding monopoly profits for the guild, depends on the parameters of the model, and the implications this has for the guild's optimal size, as well as its performance relative to the tax collector. Before providing the equilibrium analysis it is useful to frame the timing of the game within each stage. The sequence of moves within every trading period $\tau$ is as follows:

- Merchants decide whether to pay the operating cost or not.

- Demand is realized.

\footnotetext{
${ }^{29}$ The implicit assumption here is a uniform tie-breaking condition, which is standard in market games with homogenous sellers.
} 
- Merchants simultaneously and independently quote prices and decide whether to pay the exclusion cost.

- Profits are realized.

We will look for a SPNE of the game in which in every trading period guild members pay the operating cost, while they exclude outsiders and charge the monopoly price $p^{M}=\Delta$ if and only if $v^{\tau}=\Delta$. Such an outcome can enforce the monopoly outcome as long as: $(i)$ each merchant does not profit from undercutting the monopoly price; $(i i)$ it is in each merchant's best interest to pay both the operating and the exclusion costs. The punishment code is the simplest one could imagine: following any deviation (be it a price deviation or simply free-riding on exclusion and operating costs) the guild is dissolved and merchants price competitively - i.e., $p=0-$ so that each obtains a profit equal to zero, which is the lowest payoff they can obtain. In this sense the punishment is optimal. Alternatively, one could assume that if a member deviates, the other guild members exclude the deviating member at the cost of $x$, and continue to operate the guild, colluding to set the monopoly price without him. This punishment code will be preferred if it is more profitable for the guild members that do not deviate. In both cases the deviating member is punished with a zero payoff. Thus, our equilibrium analysis does not hinge on the specific way the zero-profit punishment is enforced after deviation.

The equilibrium described above must be immune to three types of deviations. First, every guild member should be willing to pay his share of the guild's operating (organization and coordination) costs. This will be the case as long as the continuation value of doing so is positive - i.e., each member's expected profit is non-negative on equilibrium path

$$
\frac{\alpha(\Delta-x(N-n))-(n-1) f}{n} \geq 0 \quad \Leftrightarrow \quad \Delta \geq x(N-n)+\frac{(n-1)}{\alpha} f .
$$

Second, every guild member should be willing to contribute to the exclusion effort. Given that the guild cannot make profits if the exclusion cost is not entirely paid, it is easy to show that each merchant will contribute as long as

$$
\Delta \geq x(N-n)
$$

which is obviously implied by (1).

Third, no guild member should be tempted to undercut the others. Formally, undercutting the monopoly price is not profitable as long as the following self-enforceability constraint holds

$$
\frac{\Delta-x(N-n)}{n}+\frac{\delta}{1-\delta}\left[\frac{\alpha(\Delta-x(N-n))-(n-1) f}{n}\right] \geq \Delta-\frac{x(N-n)}{n} .
$$

The left-hand side captures the (discounted) expected gain from cooperation, while the righthand side is the spot gain from deviation. The continuation payoff after deviation is zero given the guild's punishment code. Note that (2) implies (1). Hence, undercutting in the positive 
demand state is the only deviation that must be taken into account. Of course, deviations are not feasible when the demand state is low - see Section 6 for an extension of the model to a continuous demand state.

Rearranging condition (2), it follows that collusion is sustainable as long as

$$
\Phi(n) \equiv \underbrace{\frac{\delta \alpha}{1-\delta}[\Delta-x(N-1)]}_{\geq 0 \text { by } \mathbf{A} 1}-(n-1)\left[\Delta+\frac{\delta}{1-\delta}(f-\alpha x)\right] \geq 0 .
$$

Notice that the impact of the guild density $n$ on the self-enforceability constraint is ambiguous. In fact, differentiating with respect to $n$ we have

$$
\frac{\partial \Phi(n)}{\partial n} \geq 0 \quad \Leftrightarrow \quad x \geq \bar{x} \equiv \frac{f}{\alpha}+\frac{(1-\delta) \Delta}{\alpha \delta} .
$$

This expression suggests that there are three effects shaping the way a higher density $n$ impacts the incentive to undercut the monopoly price. First, other things being equal, as $n$ grows larger each guild member is more tempted to undercut $p^{M}$ because the monopoly profit must be shared among more people - i.e., the individual revenue from collusion $\Delta / n$ becomes smaller as $n$ increases. Second, operating costs are increasing in guild size, thus a higher $n$, by increasing coordination costs, tends to make collusion less appealing because the continuation value of cooperation shrinks. Third, a higher density reduces the cost of excluding outsiders, which (other things being equal) tends to make collusion easier to sustain since it increases the continuation value of cooperation. This effect becomes stronger when the cost of excluding each outsider $x$ grows larger. It should be noted that $\alpha$ and $\Delta$ have a quite different impact on $\bar{x}$ : a higher $\alpha$ tends to reduce it, while a higher $\Delta$ increases it. Thus $\Delta$ and $\alpha$ play a different role in the analysis.

Summing up, while the first and second effects point in the direction of making collusion harder to sustain when $n$ increases, the third effect goes in the opposite direction. We can therefore establish the following result.

Lemma 1 If $x \geq \bar{x}$ collusion is always viable in the guild regime regardless of $n$. Otherwise, collusion can be sustained if, and only if,

$$
n \leq \bar{n} \equiv 1+\frac{\Delta-x(N-1)}{\bar{x}-x}
$$

where $\bar{n}$ decreases with $f$, and increases with $\alpha, \delta, x$ and $\Delta$.

This result shows that if the exclusion cost $x$ is sufficiently large, the third effect described above dominates - i.e., when $x \geq \bar{x}$ larger guilds are more profitable because they are able to better minimize total exclusion costs. Hence, as the number of insiders grows larger it is easier to sustain the monopoly outcome, meaning that as long as a single-member guild is viable (as stated 
in assumption A1 $)^{30}$ the monopoly outcome is sustainable regardless of guild size. When instead exclusion costs are not so important and the other two effects dominate, there is an endogenous upper-bound on guild size - i.e., $n \leq \bar{n}$. Essentially, guilds that are excessively dense bear high coordination costs and are less able to deter price deviations. Hence, collusion is viable only if the guild density is not too large. This constraint becomes tighter when coordination costs are higher, as reflected by a larger $f$; it softens instead when the probability of being in a positive demand state increases, as reflected by a higher $\alpha$; when the market becomes more valuable, as reflected by a higher $\Delta$; when merchants become more patient, which is captured by a higher discount factor $\delta$; or when exclusion is more costly, as reflected by a higher $x$. For simplicity, hereafter we assume (without loss of insights) that $N>\bar{n}$.

The guild density is chosen so as to solve the following maximization problem

$$
\max _{1 \leq n \leq N} \frac{\alpha(\Delta-x(N-n))-(n-1) f}{1-\delta}
$$

subject to $\Phi(n) \geq 0$.

Note that the impact of the density on the guild's objective function is ambiguous. When $n$ increases the cost of excluding outsiders shrinks: insiders need to exclude fewer outsiders. However, as the number of insiders grows larger the guild's operating cost also increases since coordination becomes more expensive. Hence, the guild's objective function is increasing in $n$ if, and only if,

$$
x \geq \underline{x} \equiv \frac{f}{\alpha} .
$$

As we have already shown above, the impact of the density on the self-enforceability constraint is ambiguous too. This makes the choice of the guild's size a non-obvious problem. The key insight is that while the objective function is increasing in $n$ as long as $x \geq \underline{x}$, the self-enforceability constraint (2) softens as a response to a higher $n$ if $x \geq \bar{x}>\underline{x}$, meaning that even if exclusion costs are large enough to induce a positive relationship between the guild's expected profit and its density, it may well be the case that a larger density amplifies each member's incentive to undercut the monopoly price - i.e., $x \leq \bar{x}$.

Let $n^{*}$ be the optimal density and denote by $W\left(n^{*}\right)$ the value function associated with the guild's maximization problem. In the next proposition we examine how the tension between the two effects just described shapes the optimal guild size.

Proposition 2 The solution of the guild's maximization problem has an interior solution $n^{*}=$ $\bar{n} \in(1, N)$ if, and only if, $x \in(\underline{x}, \bar{x})$. Otherwise, it features a corner solution - i.e., $n^{*}=1$ when $x \leq \underline{x}$ and $n^{*}=N$ when $x \geq \bar{x}$.

Hence, the guild's ability to exclude outsiders plays a crucial role in the trade-off discussed above. This ability will depend on several factors, including the geographical and population

\footnotetext{
${ }^{30}$ We consider the case in which this assumption is violated in the section that examines extensions to the baseline model.
} 
characteristics of the polity, which may make it easier or harder to detect alien or excluded local merchants who engage in unauthorized trade, as well as the polity's openness to foreigners, and its attractiveness to alien merchants. The ability to exclude non-members from trade will also depend, on the other hand, on the degree of trust among guild members, and the extent to which they are able to overcome free-riding incentives and cooperate to monitor and intervene effectively: in other words, on their social capital. Thus social capital affects several parameters in our model: greater social capital tends to reduce exclusion costs, parameterized by $x$, and also coordination costs, parameterized by $f$, as discussed earlier.

In the following we will focus only on the most interesting case in which the optimal guild's size is interior - i.e., $x \in(\underline{x}, \bar{x})$ so that $n^{*}=\bar{n}$ - and neglect corner solutions, which are less appealing from an historical perspective (see the Appendix for a complete characterization). Solving the model backward, the Nash bargaining problem between the guild and the ruler is:

$$
\max _{R^{G} \in \Re_{+}}\left(R^{G}-V^{T}\right)^{\beta}\left(W(\bar{n})-R^{G}\right)^{1-\beta} .
$$

where, as explained before, $V^{T}$ is the ruler's outside option, which is the expected payoff he would obtain by hiring a tax-collector. The outside option of the guild is zero since merchants would make no profits if a tax-collector were hired. It is then immediate to verify that the solution of (3) entails:

$$
R^{G}=V^{T}+\beta\left[W(\bar{n})-V^{T}\right],
$$

which also defines the ruler's profit from granting recognition and privileges to a guild.

\section{Merchant guild versus tax-collector}

Building on the previous results, we can now examine under which conditions the ruler prefers to recognize a merchant guild rather than hiring a tax collector. Comparing $R^{G}$ and $V^{T}$ we find that

Proposition 3 Assume that $n^{*}=\bar{n}$. There exists a threshold $\psi^{*} \in(0,1)$ such that the ruler prefers to grant recognition to the guild if, and only, if $\psi \geq \psi^{*}$. The threshold $\psi^{*}$ is increasing in $x, f$ and $N$, and decreasing in $\Delta, \delta$ and $\alpha$.

Intuitively, the ruler's choice between the guild regime and the tax collector regime depends on the costs associated with each. The guild regime can entail two types of cost, coordination costs and exclusion costs, whose relative importance varies with guild size. These costs need to be weighed against the cost of relying on an agent to collect taxes. Proposition 3 clarifies this trade-off. It shows how the relative attractiveness of guilds depends both on their internal characteristics - i.e., their social capital, which affects $f$ and $x$ - and on characteristics of the

polity, which influence current and expected future demand, as well as the number of potentially active merchants, and the cost of excluding non-members from trade. 
Proposition 3 has clear-cut comparative statics predictions: merchant guilds are more likely to emerge, other things being equal, when $\Delta, \alpha, \delta$ and $\psi$ are higher, and $f, x$ and $N$ lower. Paucity of data for the historical period under consideration makes it very difficult to verify these empirically; nevertheless, it is possible to obtain some information from historical sources such as charters granted by rulers, municipal records, court records, and guild statutes. We consider evidence from such sources below, while emphasizing the important caveat that many records and documents from the eleventh, twelth and thirteenth centuries (and of course earlier) have been lost. Indeed, some of the important work carried out by medieval historians entailed trying to infer information about lost documents from occasional references to such documents in subsequent, surviving ones.

\subsection{Predictions and historical evidence}

Our model yields a number of implications for the emergence, operation and decline of merchant guilds. We now review the historical evidence on these predictions. Other things being equal:

- Prediction 1 (Guild emergence): Guilds are more likely to emerge when the expected profitability of trade, represented by $\Delta$ and $\alpha$, is higher.

Historically, the European economy started to grow substantially in the eleventh century: the period until the fourteenth century witnessed a dramatic increase in production, trade, and consumer demand. ${ }^{31}$ This is the period when local merchant guilds emerged and became widespread. ${ }^{32}$ Moreover, as the model would predict, merchant guilds were typically established in towns, and not in smaller market centres, where trade yielded revenue for rulers through tolls collected by officials. ${ }^{33}$ For example, merchant guilds were established early on in most of the largest ${ }^{34}$ eleventh century towns in England, as estimated on the basis of data from the Domesday Book (1086), such as Winchester, York, Lincoln, Oxford, Ipswich, Canterbury, Gloucester, Nottingham, Leicester, Bury St. Edmund's, Dunwich, and Wallingford. ${ }^{35}$ Towns such as Ludlow, Poole, and Weymouth, that began to develop during the twelth century, appear to have been granted merchant guilds later on. ${ }^{36}$

Larger towns could be expected to have both higher $\Delta$ (larger market size), and higher $\alpha$ (since greater economic diversification would tend to reduce the risk of very unfavorable demand

\footnotetext{
${ }^{31}$ Spruyt (1994, pp. 61-63).

${ }^{32}$ Dilcher (1984, pp. 72-76); Hickson and Thompson (1991, pp. 137-8); Woodward (2005, pp. 631-3). Interestingly, as pointed out by Richardson and McBride (2009), mortality rates in much of this period were low, suggesting that $\delta$ was relatively high, which is also consistent with our model.

${ }^{33}$ For many examples of such smaller market centres, and their tolls, see Britnell (2000).

${ }^{34} \mathrm{~A}$ town with at least 2000 inhabitants was 'large' at the time.

${ }^{35}$ Gross (1890, pp. 9-16), gives the following dates for the earliest reference to these towns' merchant guilds: Winchester (Henry II), York (1130-1), Lincoln (Henry II), Oxford (Henry II), Ipswich (1200), Canterbury (10931109), Gloucester (1200), Nottingham (c.1189), Leicester (1107-1118), Bury St. Edmund's (1198), Dunwich (1200), Wallingford (Henry II). The mention Henry II refers to charters given by Henry II, King of England in 1154-89.

${ }^{36}$ Gross (1890, pp. 9-16), gives the following dates for the earliest reference to these towns' merchant guilds: Weymouth (1442), Ludlow (1461), Poole (1568).
} 
states). For example, in his detailed study of the West Midlands of England, Dyer (1992, p.145) notes how "all of the towns had much in common, notably in their varied occupations - 15 or 20 are recorded for some of the lesser towns, rising to 50 in the case of Worcester ${ }^{37} \ldots$ The bigger towns gave opportunities for a wider range of specialists, as well as for traders on a large scale". Note however that larger towns are also likely to have had a larger population of potentially active merchants, $N$. Thus we would expect guilds in these towns to have had plenty of social capital, enabling them to be either large and inclusive, yet able to coordinate easily and successfully (i.e., low $f$ ), or more exclusive, with fewer, well-organized members able to cooperate successfully and deter any attempts by non-members to undermine their monopoly over trade (i.e., low $x$ ). We therefore turn to the evidence on social capital.

- Prediction 2 (Social capital): Guilds are more likely to be granted recognition if they possess more social capital, represented by lower $x$ (cost of exclusion) and $f$ (cost of coordination), enabling them to coordinate efficiently their strategies and sustain their monopoly profits.

Merchant guilds were social networks whose members participated in a variety of social and religious activities together; they held regular assemblies and feasts; when abroad, they lived in their own quarters of foreign cities and interacted closely. At home as well as abroad, they provided mutual assistance when in difficulty. ${ }^{38}$ Close and repeated interaction facilitated monitoring and the exchange of information, helping to build and sustain trust and cohesion.

The historical evidence from surviving records shows that merchant guild members cooperated to enforce and protect their exclusive rights. They did this in a variety of ways. Their exclusive rights, granted at earlier dates, were sometimes challenged in subsequent periods, and merchant guild members cooperated to defend them in court. For example, "In 1330 the major and community of the town of Bedford were summoned to answer to the king by what warrant they claim to have a Gild Merchant... so that anyone who is not of that Gild may not merchandise...". In reply to the summons, "the burgesses show a charter of Richard I, granting a Gild Merchant..." and argue their case. ${ }^{39}$ Similar examples are available for other merchant guilds. ${ }^{40}$ There are also records of merchant guild members intervening directly to enforce their exclusive rights, and then defending their intervention in court when challenged. ${ }^{41}$ For example, "In 1280 several burgesses of Newcastle-under-Lyme were summoned by the king for seizing ten fleeces of wool belonging to Richard the Baker of Stafford... They say that they seized Richard's wool because he bought it contrary to the liberty of the Gild; and they show a charter of Henry III...". ${ }^{42}$

\footnotetext{
${ }^{37}$ Our note: Worcester indeed had a merchant guild.

${ }^{38}$ Coornaert (1948, p. 218); Gross (1890, pp. 34-5).

${ }^{39}$ Gross, 1890, p. 37. Note that Richard I was King of England in 1189-1199.

${ }^{40}$ For example, Chester, Beaumaris, Conway, Bala, Newborough, Carnarvon, Harlech, Criccieth, Macclesfield (Gross, 1890, pp. 38-39, 42).

${ }^{41}$ It is precisely thanks to surviving court records that we have this kind of evidence. It seems likely that many such cases were unchallenged and hence unrecorded.

${ }^{42}$ Gross (1890, p. 39). Note that Henry III was king of England in 1216-1272. Gross (p. 14) gives 1235 as the earliest reference to the merchant guild of Newcastle-under-Lyme.
} 
Merchant guilds often opposed powerful lords: for example, "Alan Basset lord of Wycombe... attempted to get rid of the gild merchant and allow free trade in hides and wool in the town. The burgesses, in this case synonymous with the gild, brought an action against him in the King's Court (Curia Regis) claiming that they had their gild merchant by charter from King John". ${ }^{43}$

Merchant guild members successfully coordinated on profit-maximizing strategies vis-à-vis alien merchants. This did not always entail complete exclusion - in particular, restrictions were often relaxed on particular days, "no one, except a gildsman, shall buy honey, suet, salt herring, nor any kind of oil, nor mill-stones, nor fresh leather, nor any kind of fresh skins; nor keep a winetavern, nor sell cloth by retail, except on market and fair day". ${ }^{44}$ As Gross points out, "gildsmen were enlightened enough to perceive that more complete freedom of trade on those days attracted a greater multitude of people... and thus conduced to their commercial prosperity". ${ }^{45}$ Yet guild members often enjoyed preemption rights: for example, the Southampton ordinances dictated that "no simple inhabitant nor stranger shall bargain for nor buy any kind of merchandise coming to the town before burgesses of the Gild Merchant". ${ }^{46}$

Thus successful coordination and cooperation by guild members required elaboration and implementation of more complex strategies when dealing with alien merchants than simply fixing prices by guild members and excluding everyone else. These also included requirements for alien merchants to "bring their wares to 'the Common Hall' or other specified public place, and there expose them for sale, in order that their goods could be more easily examined, and their mercantile transactions more readily supervised". ${ }^{47}$ Moreover, alien merchants were often restricted to a maximum number of days they could remain in the town, and "during this time they were carefully watched, lest they should sell or buy under... cover of a faithless gild-brother's freedom, the latter being expelled from the fraternity or otherwise severely punished, if found guilty of this offence". 48

Coordination and cooperation among guild members was further enhanced by a variety of guild norms; for example, "the gildsman was generally under obligation to share all purchases with his brethren, that is to say, if he bought a quantity of a given commodity, any other gildsmen could claim a portion of it at the same price at which he purchased it". ${ }^{49}$

- Prediction 3 (Guild decline): Guilds are more likely to decline when the cost of relying on agents to collect taxes $(\psi)$ decreases, and when characteristics of the polity make it harder for guilds to enforce their monopolies over trade (increasing $x$ and/or $f$ ).

\footnotetext{
${ }^{43}$ The quotation is from Fryde (1985, p. 222), citing as source: Curia Regis Rolls of the Reign of Henry III, vol. XI, 7-9 Henry III (London 1955), p. 415, no. 2055.

${ }^{44}$ Extract from the ordinances of Southampton, cited by Gross (1890, p. 47).

${ }^{45}$ Gross (1890, p. 47).

${ }^{46}$ Gross $(1890, \mathrm{p} .48)$.

${ }^{47}$ Gross (1890, p. 47).

${ }^{48}$ Gross (1890, p. 48).

${ }^{49}$ Gross (1890, p. 49). For many more examples, see Dessí and Ogilvie (2004) and Ogilvie (2011).
} 
The timing of merchant guilds' decline varied across countries. According to Ogilvie (2011, pp. 31), it started "after about 1500, although for a long time... largely restricted to two areas of Europe - the Low Countries (modern Belgium and the Netherlands) and England". 50 The reasons for merchant guilds' decline are a matter of debate among historians - there were in all probability multiple reasons. Can our model shed any light on the decline of merchant guilds? We consider three important examples below: England, the Low Countries, and northern Germany.

England. Schofield (2004) highlights the increasing importance of the directly assessed subsidy in England during the sixteenth century. This was an individual tax, "levied upon the assessed wealth of each taxpayer" (p. 2). Schofield shows how this tax evolved from a means to raise revenue in extraordinary circumstances (typically times of war or imminent war) to a more generally acceptable contribution to the funding of government. The timing is of considerable interest: "the act of 1534 is revolutionary in that it is the first act that justifies parliamentary taxation primarily in terms of the civil benefits conferred on the realm by the excellence of the king's government" (p. 13 ). In terms of our model, the evolution of this tax can be thought of as equivalent to a reduction in $\psi$, which makes it consistent with merchant guild decline starting in the 16 th century. ${ }^{51}$

Evidence on changes in the cost of enforcing merchant guilds' monopolies in England is harder to obtain directly. However, we do know that there was significant trading activity in the countryside, in informal as well as formal trading centres: Dyer (1992) discusses many examples of this 'hidden trade' for the 14th, 15th and 16th centuries. Opportunities for merchants excluded from guilds to profit from such trade must have been limited early on. They must have grown substantially between 1300 and 1600, because of the following changes reviewed by Britnell (2000, pp. 12-13): (i) a "severe reduction in the proportion of the population who might be classified as cotters or labourers" (i.e. the poorer families); (ii) a "rising standard of living in rural society", associated with an "increased demand for merchant wares"; (iii) an "increasing propensity of consumers to buy goods from abroad"; $(i v)$ the "increasing importance of exported manufactures for English employment and national income". Moreover, export-led production increased not only in large towns, but also in small towns and rural areas. For example, if we look at English cloth ${ }^{52}$ production, we find that "In the first significant phase of export growth between 1350 and 1400 the chief beneficiaries were older towns... In the second main phase from

\footnotetext{
${ }^{50}$ Ogilvie (2011) focuses on the guilds' gradual loss of power and decline. See also Hickson and Thompson (1991), who focus instead on one step in this process of decline, the elimination of guild entry restrictions.

${ }^{51}$ Johnson and Koyama (2014) also draw attention to how, following the Glorious Revolution of 1688, "the English state borrowed on a new scale; Parliament gained control of expenditure and, from 1693 onwards, guaranteed loan repayment; the Bank of England, formed in 1694, began to issue long-term loans which now comprised a national debt... and a secondary market grew up that securitized this new debt". As we shall see below, one of the ways in which merchant guilds benefited medieval rulers, in return for their privileges, was the provision of large loans that helped to alleviate their financing constraints. The increased ability to borrow from other sources in the 18th century thus further reduced the value of merchant guilds to the English state.

${ }^{52}$ Cloth became one of England's most important exports.
} 
the 1470s the chief beneficiaries were the rural or small-town industries of western Wiltshire, Devon and elsewhere". ${ }^{53}$

In sum, higher rural demand must have created profitable opportunities for merchants, including merchants who were not guild members, who could sell imported goods to rural inhabitants, buy from them goods to be sold abroad, and increasingly trade with them goods produced in different parts of the country. Indeed, by the sixteenth century, we observe a substantial development of 'mercantile' networks "that made it advantageous for artisans to live in particular towns and industrial villages, especially if they were producing goods in demand over considerable distances. Local trade between village weaver and village tanner had given way, in part, to trade over longer distances with merchant intermediaries... non-agricultural activity grew in rural areas, but it was characteristically more merchant-dependent than in the thirteenth century". 54

In other words, merchant guilds' costs of preventing non-members from undermining their profits $(x)$ increased substantially by the sixteenth century - which is consistent with merchant guild decline starting in this period. As we have seen, improvements in taxation further tilted the balance against merchant guilds, contributing to their decline.

The Low Countries. The Low Countries are the other area of Europe where, according to Ogilvie (2011, p. 31), merchant guilds declined after about 1500. Although the context was different from England, here too local merchant guilds faced increasing costs of preventing nonmembers from undermining their profits $(x)$ : according to Gelderblom (2013), neighbouring cities competed fiercely to attract foreign merchants, because of their geographical position at the heart of the European international trading network. A good example is given by Bruges, the first city in the Low Countries to emerge as a major international commercial centre. Bruges faced little competition from other cities in the Low Countries until the development of the Brabant fairs in Antwerp and Bergen-op-Zoom starting in the fourteenth century. ${ }^{55}$ By the midfifteenth century, "Hundreds of artisans and merchants, local and foreign, regularly traveled to Brabant" 56 , and by the end of the century, Antwerp had overtaken Bruges ${ }^{57}$. This is consistent with merchant guild decline beginning in the sixteenth century.

As for taxation, Fritschy (2003) discusses the "tax revolution" in Holland in the sixteenth century, leading to a dramatic increase in revenue from 1574 onwards. This can be interpreted in terms of a reduction in $\psi$ in our model, further contributing to merchant guild decline.

The German Hanse. Northern Germany, on the other hand, is one of the examples typically given of slower decline of merchant guilds. In this part of Europe a large number of cities, rather than competing with each other, had formed a powerful association, the Hanseatic League

\footnotetext{
${ }^{53}$ Britnell (2000, p. 14).

${ }^{54}$ Britnell (2000, pp. 20-21).

${ }^{55}$ See Gelderblom (2013, pp. 20; 25-26).

${ }^{56}$ Gelderblom (2013, p. 27).

${ }^{57}$ Gelderblom (2013, p. 15).
} 
(Hanse). By coordinating their actions, the members of the German Hanse were able to obtain substantial commercial privileges for their merchants trading in northern Europe ${ }^{58}$, acquiring a dominant position in Baltic trade. Merchant guild members in Hanse cities continued to earn the resulting profits from trade until eventually the rise of Dutch and English shipping undermined their monopoly.

The timing of decline is summarized by Lindberg (2009, p. 609): "By the end of the fifteenth century, the Dutch had a clear dominance over Baltic trade, although the richest trades, such as spices, remained in the hands of the Hansa merchants. After the fall of Antwerp, in 1585, Amsterdam emerged as northern Europe's economic centre, and Dutch control of the Baltic spice trade during this period marked the end of the dominant rule of the Hanseatic cities within European trade". Thus the cost of preventing non-members from undermining their profits $(x)$ increased gradually over a long period of time for the local merchant guilds of the Hanseatic cities, and decline was correspondingly slow. ${ }^{59}$

As for taxation, Hanseatic cities followed different paths over time, belonging to different territories and jurisdictions (empire, different kinds of kingdom, duchy, archbishopric, principality, etc.). Dincecco (2009) shows that in Prussia, where some of them ended up, per capita revenues remained substantially lower than in Britain or the Netherlands until the 19th century, which is also consistent with a slower decline of merchant guilds.

- Prediction 4 (Guilds, rulers and transfers): Guilds will make transfers to rulers in return for their privileges, and they will be exempted from tolls imposed by tax collectors.

In our model, under the 'guild' regime, merchant guild members are exempted from taxation by a tax collector, and use (part of) their collusive profits to make direct transfers to rulers.

The historical evidence shows that merchant guilds were indeed granted exemptions from a variety of tolls and other taxes, and made direct transfers to their rulers. ${ }^{60}$ In England, for example, the same town charters that granted legal recognition and monopoly privileges to the local merchant guild generally granted exemptions from all tolls and other taxes, in exchange for a fixed sum or farm (firma burgi) to be paid annually by the town to the ruler (Gross, 1890). Membership of the local merchant guild carried corresponding duties and benefits: chief among the obligations was participation in the town's assessments and payment of pecuniary charges, which ensured that the firma burgi was duly paid and the privileges granted in the charter maintained. On the benefit side, local guild members enjoyed the right to trade freely and were

\footnotetext{
${ }^{58}$ See for example Dollinger (1970, pp. 189-190) on the privileges obtained by the German Hanse in England and Flanders.

${ }^{59}$ On the other hand, once the cost became high because the network of alternative trading centres and trading routes had developed sufficiently, attempts by local merchant guilds to enforce local monopolies ultimately led to stagnation and decline (for examples, see Lindberg $(2009,2010)$ on Lubeck and Konigsberg, two of the most important Hanseatic cities).

${ }^{60}$ For examples see, among others, Ehbrecht (1985, pp. 425-6), on Germany; Hoffmann (1980, p.49), on Denmark; Racine (1985, pp. 135-6), on Italy; Smith (1940, pp. 48, 64-5, 85), and Woodward (2005, pp. 631-4) on Spain.
} 
generally exempt from all tolls, while "unfranchised merchants, when allowed to practise their vocation, were hemmed in on every side by onerous restrictions. Of these the most irksome was probably the payment of toll on all wares that they were permitted to buy or sell", Gross (1890).

In Flanders, a similar pattern can be observed from the early twelth century: the town of St. Omer obtained freedom from all tolls and other taxes in 1128 in return for a fixed annual sum or farm. ${ }^{61}$ The local merchant guild in St. Omer enjoyed a variety of monopolistic privileges and contributed to the provision of local public goods.

There is evidence of direct cash transfers made by local merchant guilds to rulers throughout Europe, from England and Germany to Italy and Spain. ${ }^{62}$ In addition to direct cash transfers, other forms of transfer were widespread, yielding substantial benefits for rulers. Thus local merchant guilds provided valuable assistance with the collection of trade taxes (taxes on merchants that were not exempt). ${ }^{63}$ They also helped to alleviate medieval rulers' financing constraints by providing large loans, at a time when borrowing large amounts was not easy for rulers. ${ }^{64}$ Finally, local merchant guilds were an important source of naval and military assistance, and political support, for medieval rulers. ${ }^{65}$

\subsection{Additional implications and historical evidence}

Beyond the predictions just discussed, our analysis yields several other implications. We now discuss these, together with the historical evidence on them.

- Prediction 5 (Exclusive membership and merchant inequality): Guilds may impose restrictions on membership, and these may generate wealth inequality among merchants

In our model, the negative implications of guilds for equality among merchants arise when the following three conditions are satisfied: $(i)$ the optimal guild size falls short of the total number of potentially active merchants (i.e., $\left.n^{*}<N\right)$; $(i i)$ the merchant guild generates a surplus relative to the revenues that would be raised by a tax collector (i.e., $\left.W\left(n^{*}\right)>V^{T}\right)$; $(i i i)$ the merchant guild has sufficient social capital, and hence bargaining power, to secure part of

\footnotetext{
${ }^{61}$ See Lyon and Verhulst (1967).

${ }^{62}$ Dagron (2002, p.408); Freshfield (1938, p. 17); Kohn (2003, p.44); Lloyd (1977, p. 120); Racine (1985, pp. 135-6, 139); Schütt (1980, pp. 112-21); Smith (1940, pp. 48, 64-5); Woodward (2005, pp. 631-4). For reviews and discussions see Dessí and Ogilvie (2004, pp. 38-39) and Ogilvie (2011, p. 169).

${ }^{63}$ Ashtor (1983, pp. 73-4, 271-83); Bernard (1972, p. 327); Fryde (1959, pp. 2-8); Ormrod (2000, p. 292); Postan (1987, p. 293); Smith (1940, pp. 61-4, 86); Woodward (2005, pp. 632-4). For reviews and discussions see Dessí and Ogilvie (2004, pp.39-40), Ogilvie (2011, pp. 171-172).

${ }^{64}$ Abulafia (1987, pp. 440-1); Ashtor (1983, pp. 73-74, 271-83); Becker (1960, pp. 40, 44); Planitz (1940, p. 73); Postan (1987, pp. 292-3); Smith (1940, pp. 37, 48, 64-5, 85); Woodward (2005, pp. 631-3). See Dessí and Ogilvie (2004, pp. 57-59), and Ogilvie (2011, p. 176) for reviews and discussions.

${ }^{65}$ Blockmans (2000, p. 414); Congdon (2003, pp. 224-5); Dilcher (1984, p. 70); Nicholas (1997, p. 133); Postan (1987, p. 293); Smith (1940, pp. 48, 64-5); Spruyt (1994, p. 114); Woodward (2005, p. 633). For reviews see Dessí and Ogilvie (2004, pp.38-39, 61); Ogilvie (2011, pp. 178, 180-182).
} 
the surplus it generates (i.e., $\beta<1$ ). In this case, guilded merchants will enjoy higher profits than excluded merchants.

Did local merchant guilds restrict membership? Historically, the answer is yes: membership was often contingent on having 'citizenship' or 'burgess' or 'free' status, from which many were excluded. ${ }^{66}$ As towns grew, attracting large numbers of rural immigrants, this exclusion affected an increasing number of urban inhabitants. In England for instance, "big towns had populations most of whose members were not 'free' - e.g., two thirds in late-thirteenth-century in London, a half in Oxford and more than three quarters in Exeter" (Hilton, 1992, pp. 92).

A key requirement for membership of local merchant guilds was the payment of entry fees and a variety of dues $^{67}$, which is consistent with our model (members collectively needed to fund transfers to the ruler). This implied the exclusion of those who could not afford to pay the, often substantial, entry fees, or who were unable to provide the required guarantees: "To become a gildsman...it was necessary to pay certain initiation-fees... The new comer was also required to produce sureties, who were responsible for the fulfilment of his obligations to the Gild - answering for his good conduct and for the payment of his dues" (Gross, 1890, pp. 28). The historical evidence makes it clear that many of the towns' inhabitants could not meet these requirements. ${ }^{68}$ Moreover, admission to local merchant guilds was sometimes controlled by requiring that the potential new member be approved by a majority of existing members, and this requirement appears to have been used to restrict membership. ${ }^{69}$

In sum, local merchant guilds excluded an increasing proportion of the urban population, notably the least wealthy.

- Prediction 6 (Guilds' social capital and town government): Guilds with lower coordination costs $(f)$ are more likely to engage in other collective activities that benefit guild members

Our analysis highlights the importance of merchant guilds' social capital in reducing members' costs of coordination and organization. An important implication of this is that guilds with substantial social capital were likely to engage in additional collective activities - beyond those required to enforce successfully, and profit from, their exclusive rights over trade - which were in their members' collective interest. Perhaps the most important example of this is the role played by merchant guilds in the emergence of town government throughout medieval Europe.

\footnotetext{
${ }^{66}$ See Dilcher (1985, pp. 88-9), Epstein (2000, pp. 35-6), Leguay (2000, pp. 110-1, 121-2), Schütt (1980, p. 131), and Spruyt (1994, pp. 144).

${ }^{67}$ For examples see Ehbrecht (1985, p. 445), on entry fees for the merchant guild of Goslar; Dilcher (1984, p. 69), and Volckart and Mangels (1999, pp. 437-8), on dues levied by the merchant guild of Tiel; Schütt (1980, pp. 112-21), on the dues levied by the merchant guild of Flensburg; Störmer (1985, pp. 366-7), on entry fees for the merchant guild of Laufen; Origo (1986, p. 44), on entry fees for the merchant guild of Prato.

${ }^{68}$ See Hilton (1992, p. 92), and Schultze (1985, pp. 379-81).

${ }^{69}$ See Smith (1940, p. 38).
} 
Fryde (1985, pp. 216-7), reviewing the contributions to English historiography by Tait $(1936)^{70}$ and Martin (1963) ${ }^{71}$, notes how "in some towns the gild provided the first administration independent of the town lord, set up by the townsfolk themselves, regardless of whether the lord was the king, a nobleman or a great abbot... a large proportion of the so-called borough records which survive from the thirteenth century are, in fact, gild records". Moreover, guilds often took on tasks normally undertaken by local government: "in Leicester and Bristol for instance, the gild was responsible for road, bridge and wall building and the gild chest fulfilled the role of a town treasury".

In Germany, merchant guilds in towns such as Cologne played a key role in gaining autonomy from feudal lords, and directing the administration of the town (Dollinger, 1964, pp. 27-28). A similar pattern can be found throughout Italy (Racine, 1985, pp. 142-44). In Flanders too, guilds played an important role in the politics and administration of towns such as Arras, Bruges, Ghent, Lille, Saint-Omer. ${ }^{72}$

\section{Extensions}

The analysis developed up to this point hinges on a few simplifying assumptions. In this section we show that its basic insights carry over when these are relaxed, and obtain some additional implications.

Downward sloping demand and production costs. Our results clearly do not hinge on assuming a unit demand or normalizing merchant costs to zero. To see this, consider a setting in which merchants face a downward-sloping demand curve for their product, say $D(p)$, and a unit cost $c>0$. We abstract from uncertainty for simplicity - i.e., normalize $\alpha=1$.

Letting

$$
p^{M} \equiv \underset{p}{\arg \max } D(p)(p-c),
$$

be the monopoly price, we can define the monopoly profit as

$$
\Delta \equiv D\left(p^{M}\right)\left(p^{M}-c\right)
$$

It is then easy to show that the tax collector solution will entail setting a unit tax such that the equilibrium price will be the monopoly price - i.e., $t^{\tau}=p^{M}-c$ for every $\tau$ - and the tax collector will extract all the merchants' profits. Similarly, all the results derived in the regime with a guild will go through, with the difference that now $\Delta$ represents the monopoly profits.

Allowing explicitly for merchant costs is interesting because it highlights another important role for guilds: securing goods at the lowest possible cost to their members, thereby maximizing

\footnotetext{
${ }^{70}$ The Medieval English Borough (Manchester 1936).

${ }^{71}$ G. H. Martin, The English borough in the Thirteenth Century, Transactions of the Royal Historical Society, 5th ser. 13 (1963, p. 131).

${ }^{72}$ Coornaert (1948, p. 216).
} 
monopoly profits. In particular, it is clear from the analysis that the same coordination and collusion ability that allows guild members to exercise monopoly power efficiently relative to consumers can help them to exercise monopsony power relative to suppliers. Indeed, the preemption rights imposed by guilds on alien merchants (discussed earlier) can be interpreted as facilitating the exercise of such monopsony power.

Imperfect commitment. Our baseline analysis assumed that the ruler can make long-term commitments. Thus both regimes entailed a single ex-ante transfer to the ruler: the tax collector paid for his future tax revenues from obtaining the tax farm, while the merchant guild paid for its future profits from being given recognition and privileges (exclusive trading rights). If the ruler cannot make long-term commitments, the single ex-ante transfer will be replaced by a fee paid to the ruler at the beginning of every period. For the tax collector, this makes no difference: each period, before observing the realization of demand, he pays his fee to the ruler, which is the expected value of what he will raise this period. Then he observes the realization of demand: if it is high he sets the tax rate $t^{\tau}=\Delta$ and collects the resulting tax revenues; if it is zero there is no trade and hence no tax revenues.

Under the guild regime, the equivalent of this is that at the beginning of each period, before observing the realization of demand, guild members get together and collectively pay the ruler a fee, equal to a share $\beta$ of the expected value of their net joint profits in that period. If anyone does not pay his share of this fee, the guild is abolished, and all merchants make zero profits from then on. The key difference between this setting and the one with a single ex-ante transfer to the ruler is that merchants' expected future returns from collusion now have to take into account the future fees to be paid to the ruler, which makes it harder to sustain collusion: formally, the effect is akin to the effect of the coordination and organization cost $f .{ }^{73}$

Thus imperfect commitment tends to make the guild regime less attractive, relative to the tax collector regime. One implication is that kings and powerful lords should have been more likely to grant recognition and privileges to merchant guilds than smaller, less powerful lords, since they had greater commitment power, other things held equal.

We investigated this implication using the list of English merchant guilds in Gross (1890, pp. 9-16). Of these, we found that $66 \%$ had been granted recognition and privileges by kings, and $16 \%$ by lords. For the remainder, it was difficult to establish whether the privileges were first granted by kings or lords, because some early documentation has been lost, and privileges were often confirmed at later dates by subsequent charters (typically by kings). Even if we assume that in all these cases the privileges were first granted by lords, it is clearly the case that the majority of merchant guilds were granted recognition and privileges by kings rather than lords. Moreover, the $16 \%$ figure includes merchant guilds granted by powerful lords such as Robert Fitz-Hamon, Archbishop Thurstan of York, and Richard, 1st Earl of Cornwall (second son of

\footnotetext{
${ }^{73}$ In practice, the historical evidence shows that transfers to rulers were often made once a year, while the appropriate unit for our trading 'period' was the trading day. This suggests that rulers did have some commitment power.
} 
King John).

Risk averse merchants. In our environment merchants, as well as the tax collector, are risk neutral. What would happen if they were risk averse? In particular: how would risk-aversion alter the trade-off between the guild and the tax-collector regimes? The answer is simple: other things being equal, risk-aversion can only make collusion more difficult to sustain in the guild regime, and hence favor the tax-collector solution. This is because risk-averse merchants will value less than risk-neutral merchants the uncertain future stream of collusive profits, and thus attach a lower weight to the continuation value of being in a collusive equilibrium, relative to the spot gain from a unilateral deviation. Thus in the presence of risk-averse merchants, demand uncertainty makes it harder to sustain collusion.

On the other hand, recent work by Abramitzky (2008) on the insurance role of a different institution, the Israeli Kibbutz, suggests that merchant guilds might also have offered some insurance benefits to risk-averse merchants, not available under the tax collector regime. The historical evidence supports this conjecture. One example we have already discussed is the role of merchant guilds in the government of medieval towns: this clearly helped to reduce the risk of a local administration and regulations unfavorable to merchants. Another example, based on evidence from guild statutes, is provided by Gross (1890, pp. 34-5): "Attendance at the funeral of deceased members, prayers for the dead, assistance to brethren in sickness, poverty and distress... are some of the precepts inculcated by the statutes".

Further extensions. In the Appendix we show that the insights of the analysis do not change when some of analytical restrictions made in the baseline model are weakened. Specifically, we show that results do not change qualitatively when: there are exogenous constraints on the guild size, exclusion is non-deterministic and the state of demand is continuous rather than being binary.

\section{Concluding remarks}

This paper has developed a theory of the emergence, operation and decline of merchant guilds. We have examined the costs and benefits to medieval rulers of granting recognition and exclusive rights to trade to merchant guilds, together with tax exemptions, in return for direct transfers. Our theory has highlighted the role of the guilds' social capital in sustaining collusion, which is crucial for their ability to deliver sufficient benefits to rulers.

It is useful at this point to review alternative theories of merchant guilds, and relate them to our model. Greif et al. (1994), as noted earlier, provide a theory of the development of alien merchant guilds: that is, guilds of foreign (alien) merchants in a particular polity, who were granted recognition by the ruler of that polity. Their focus, therefore, differs from ours: we propose a theory of the development of local merchant guilds - i.e., guilds of local merchants in a particular polity, who were granted recognition (and privileges) by the ruler of that polity. 
Historically, the vast majority of merchant guilds emerged as local merchant guilds: only a subset of these went on to establish foreign branches, or consulates, in other polities - i.e. alien merchant guilds. Local merchant guilds dominated local trade and had a substantial impact on the development of medieval towns: to our knowledge, we provide the first formal model of this important historical institution.

It is nevertheless interesting to compare the two theories. The crucial ingredient of the Greif et al. theory is imperfect commitment by the ruler. We saw in the previous section that this does not provide an explanation for the emergence of local merchant guilds. In their model, it provides an explanation for the emergence of alien merchant guilds, as follows. The ruler can expropriate alien merchants who come to trade in his polity, or fail to provide a commercially secure environment. This reduces trade below the efficient level. The ruler would therefore like to commit not to 'misbehave' (expropriation, commercial insecurity). He cannot do so credibly unless alien merchants can, in turn, credibly threaten to boycott trade in the polity if the ruler misbehaves. This requires alien merchants to belong to an organization able to enforce its members' compliance with any trade embargo imposed by the organization: a 'guild'.

Interestingly, this provides a clear link with our work: in our theory, the most successful merchant guilds are those with higher social capital (lower $x$ and $f$ ), enabling them to coordinate successfully and jointly undertake actions in their members' collective interest. We would, therefore, expect such local merchant guilds to establish foreign branches when a sufficient number of their members engaged in international trade. These foreign branches would coordinate members' actions in foreign polities, and their relationship with the rulers of these polities (including possible trade embargoes), in the members' collective interest. The historical evidence shows this is what happened: indeed, members had to belong to the local guild of their polity of origin in order to be admitted to any of its foreign branches, and the local guild enforced punishments against members who 'misbehaved'. Moreover, as our model would predict, alien merchant guilds often secured tax exemptions in return for direct transfers to rulers of the polities where they traded. Thus our theory can easily accommodate the development of alien merchant guilds, and shed light on their operation.

A different possible explanation for the emergence of merchant guilds concerns the ruler's time preference ${ }^{74}$ : rulers sometimes needed to raise substantial revenues to fund current expenditures (e.g., wars), and may have attached a greater weight to the present than merchants. However, this does not provide a compelling case for reliance on merchant guilds rather than, for example, tax farming ${ }^{75}$. Indeed, our analysis has examined the trade-offs involved in choosing between these two alternatives. Historians such as Gross (1890) and Brentano (1870) have

\footnotetext{
${ }^{74}$ Ogilvie (2011, p. 162) suggests this, pointing out that rulers were likely to discount the future more than merchant guilds.

${ }^{75}$ Dessí and Ogilvie (2004) argue that merchant guilds were attractive to rulers because they were deep-pocket organizations, able to pool their members' resources, while tax collectors were typically capital-constrained. However, this too does not provide a compelling argument for the emergence of merchant guilds rather than, for example, associations of tax collectors (tax farmers).
} 
given us invaluable insights into the evolution and operation of merchant guilds. However, their accounts, sometimes highly critical of merchant guilds' collusive practices, do not explain why medieval rulers were happy to grant merchant guilds recognition and privileges, including the exclusive rights to trade on which these collusive practices were based.

This paper has proposed a unified theory, able to reconcile previous explanations and the large body of historical evidence on medieval merchant guilds. In doing so, it has also shed some light on the role of the guilds' social capital, and its importance for taxation, and the development of towns and their government in medieval Europe.

Finally, some remarks about welfare. Obviously, a full evaluation of the welfare consequences of medieval merchant guilds is beyond the scope of the present paper. Nevertheless, we can say something. Our analysis has shown that the impact of merchant guilds on social welfare was complex. Clearly, any attempt to evaluate the efficiency implications of the emergence of medieval merchant guilds requires a plausible historical counterfactual. From the perspective of medieval rulers seeking to raise revenues from the taxation of local trade, reliance on tax collectors (tax farmers) seems a plausible counterfactual. By comparing the merchant guild regime with the tax collector regime, we have been able to characterize the circumstances in which the merchant guild regime represents an efficiency improvement, making it possible to minimize the costs involved in raising the desired revenue. While this clearly benefits rulers and guilded merchants, who share the gains, it generally leaves consumers indifferent, since the prices they have to pay in the guild regime are the same as they would have to pay in the tax collector regime. The exception occurs for realizations of demand that require guilded merchants to coordinate on a price lower than the monopoly price: in this case consumers are better off with the merchant guild regime.

Overall, this points to a positive assessment of the welfare impact of the emergence of merchant guilds. However, we need to be cautious in our conclusions. Merchant guilds' social capital helped their members to collude effectively, and secure a share of collusive profits, but this sometimes required exclusion of individuals who would have liked to become guild members. While these individuals were not economically worse off than they would have been in the tax collector regime, the merchant guild regime did foster inequality within the merchant class, between increasingly wealthy guilded merchants and those who were excluded from their profitable trade. Similarly, we have seen that guilded merchants' social capital helped them play an important role in the development and administration of medieval towns, and in gaining autonomy from feudal lords. But it also enabled them, in many cases, to impose rules that benefited them relative to producers, fostering inequality between merchants and craftsmen. 


\section{References}

[1] Abramitzky, R., "The Limits of Equality: Insights from the Israeli Kibbutz", Quarterly Journal of Economics, 123(3), (2008), 1111-1159.

[2] Abulafia, D., "Asia, Africa, and the trade of medieval Europe", in The Cambridge Economic History of Europe, Vol. 3: Economic Organization and Policies in the Middle Ages, M. M. Postan and E. Miller (eds.), Cambridge, (1987), 402-73.

[3] Ashtor, E., The Levant Trade in the Later Middle Ages, Princeton, (1983).

[4] Bahr, K., Handel und Verkehr der Deutschen Hanse in Flandern während des vierzehnten Jahrhunderts (Leipzig, 1911).

[5] Baldwin, J., The Government of Philip Augustus, (Berkeley, 1986).

[6] Bardhan, P.. "The nature of institutional impediments to economic development", (March 3, 1996), Center for International and Development Economics Research Paper C96-066. http://repositories.cdlib.org/iber/cider/.

[7] Becker, M. B., "The Republican city state in Florence: an inquiry into its origin and survival (1280-1434)", Speculum, 35(1), (1960), 39-50.

[8] Bernard, J., "Trade and finance in the Middle Ages: 900 to 1500", in Cipolla, C. M., and Borchardt, Knut (eds.), The Fontana economic history of Europe, vol. I: The Middle Ages, (London, 1972), 274-329.

[9] Bisson, T. N., The Crisis of the Twelfth Century: Power, Lordship, and the Origins of European Government, (Princeton University Press, 2009).

[10] Blockmans, W., "Flanders", in The New Cambridge Medieval History, Vol. V: c. 1198-c. 1300, D. Abulafia (ed.), Cambridge, (2000), 405-18.

[11] Boldorf, M. "Socio-economic institutions and transaction costs: merchant guilds and rural trade in eighteenth-century Lower Silesia", European Review of Economic History, (2009), $13,173-198$.

[12] Bonney, R., (ed.) The Rise of the Fiscal State in Europe c.1200-1815, OUP, Oxford, 1999.

[13] Bourdieu, P., "The forms of capital", in Richardson, J. G. (ed.) Handbook of Theory and Research for the Sociology of Education, (Westport, CT, 1986).

[14] Brentano, L., On the History and Development of Gilds and the Origin ofTrade-Unions. London: Trübner \& Company, 1870.

[15] Brewer, J., The sinews of power: war, money and the English state, 1688-1783 (London, 1989).

[16] Britnell, R., "Urban demand in the English economy, 1300-1600", in Trade, Urban Hinterlands and Market Integration c.1300-1600, ed. J.A. Galloway (2000).

[17] Choroskevic, A. L., "Der deutsche Hof in Novgorod und die deutsche Herberge in Venedig im 13./14. Jahrhundert. Eine vergleichende Vorstudie", in Pelc, Ortwin, and Pickhan, Gertrud (eds.), Zwischen Lübeck und Novgorod, (Lüneburg, 1996), 67-87.

[18] Coleman, J. S., Foundations of social theory, (Cambridge, MA, 1990).

[19] Congdon, E. A., "Venetian and Aragonese/Catalan relations: protectionist legislation in 1398-1404", Medieval Encounters, 9(2-3), (2003), 214-35. 
[20] Coornaert, E. "Les ghildes médiévales (Vème -XIVème siècles). Définition - évolution", Revue Historique (1948), 199(2), 208-243.

[21] Dagron, G., "The urban economy, seventh to twelfth centuries", in The Economic History of Byzantium: From the Seventh through the Fifteenth Century, A. E. Laiou (ed.), Washington DC, (2002), 393-461.

[22] Dasgupta, P., and Serageldin, I. (eds.), Social capital: a multifaceted perspective, (Washington, 2000).

[23] De Roover, R., "The organization of trade", in Postan, M. M., Rich, E. E., and Miller, Edward (eds.), The Cambridge economic history of Europe, vol. III: Economic organization and policies in the Middle Ages, (Cambridge, 1963), 42-118.

[24] Dessí, R., and Ogilvie, S., "Social capital and collusion: the case of merchant guilds", Cambridge Working Papers in Economics (2004), University of Cambridge.

[25] Dijkman, J.E.C., Shaping Medieval Markets: The Organisation of Commodity Markets in Holland, c.1200-c.1450 (Leiden, 2011).

[26] Dilcher, G., "Die genossenschaftliche Struktur von Gilden und Zünften", in Schwineköper, Berent (ed.), Gilden und Zünfte (Sigmaringen, 1985), 71-112.

[27] Dilcher, G., "Personale und lokale Strukturen kaufmännischen Rechts als Vorformen genossenschaftlichen Stadtrechts", in Friedlan, Klaus (ed.), Gilde und Korporation in den nordeuropäischen Städten des späten Mittelalters, (Köln/Wien, 1984), 65-78.

[28] Dincecco, M. "Fiscal centralization, limited government, and public revenues in Europe, 1650-1913", Journal of Economic History, (2009), 69(1), 48-103.

[29] Dollinger, P., The German Hansa, (London, 1970).

[30] Dyer, C., "The hidden trade of the Middle Ages: evidence from the West Midlands of England", Journal of Historical Geography (1992), 18(2), 141-157.

[31] Ehbrecht, W., "Beiträge und Überlegungen zu Gilden im nordwestlichen Deutschland, (vornehmlich im 13. Jahrhundert)", in Schwineköper, Berent (ed.), Gilden und Zünfte, (Sigmaringen, 1985), 413-50.

[32] Epstein, S. A., "Urban society", in Abulafia, David (ed.), The new Cambridge medieval history, vol. V: c. 1198 - c. 1300, (Cambridge, 2000), 26-37.

[33] Epstein, S.A., Wage Labor and Guilds in Medieval Europe, Chapel Hill, University of North Carolina Press, (1991).

[34] Freshfield, E. H., Roman Law in the Later Roman Empire: Byzantine Guilds, Professional and Commercial. Ordinances of Leo VI c. 895 from the Book of the Eparch, Cambridge, (1938).

[35] Fritschy, W., "A 'financial revolution' reconsidered: public finance in Holland during the Dutch Revolt, 1568-1648", Economic History Review, (2003), 56(1), 57-89.

[36] Fryde, E. B., "The English farmers of the Customs, 1343-51", Transactions of the Royal Historical Society, 5th ser. (9), (1959), 1-18.

[37] Fryde, N. "Gilde in England before the Black Death", in Schwineköper, Berent (ed.), Gilden und Zünfte, (Sigmaringen, 1985). 
[38] Gelderblom, O., Cities of Commerce: The institutional foundations of international trade in the Low Countries, 1250-1650, Princeton University Press, (2013).

[39] Gelderblom, O. and R. Grafe, "The Rise and Fall of the Merchant Guilds: Re-thinking the Comparative Study of Commercial Institutions in Premodern Europe", Journal of Interdisciplinary History, (2010).

[40] Glaeser, E. L., Laibson, D., and Sacerdote, B., "An economic approach to social capital", Economic Journal, 112, (2002), 437-58.

[41] Greif, A., Milgrom, P., and Weingast, B. R., "Coordination, commitment, and enforcement: the case of the merchant guild", Journal of Political Economy, 102 (1994), 745-76.

[42] Gross, C., The Gild Merchant: A Contribution to British Municipal History, Volume I (Oxford, 1890).

[43] Guiso, L., Sapienza, P., and Zingales, L. "The role of social capital in financial development", American Economic Review, 94, (2004), 526-556.

[44] Hibbert, A. B., "The economic policies of towns", in Postan, M. Michael, Rich, E. E., and Miller, Edward (eds.), The Cambridge economic history of Europe, vol. III, Economic organization and policies in the Middle Ages, (Cambridge, 1963), 157-229.

[45] Hickson, C.R., and E.A. Thompson, "A New Theory of Guilds and European Economic Development", Explorations in Economic History (1991), 28, 127-168.

[46] Hilton, R. H., English and French Towns in Feudal Society, (Cambridge, 1992).

[47] Irsigler, F., "Zur Problematik der Gilde- und Zunftterminologie", in Schwineköper, Berent (ed.), Gilden und Zünfte, (Sigmaringen, 1985), 53-70.

[48] Johnson, N. D., and M. Koyama, "Tax farming and the origins of state capacity in England and France", Explorations in Economic History, (2014), 51(1), 1-20.

[49] Kohn, M., "Merchant associations in pre-industrial Europe", Dartmouth College Department of Economics Working Paper, (2003).

[50] Kuske, B., "Der Kölner Stapel und seine Zusammenhänge als wirtschaftspolitisches Beispiel", Jahrbuch des Kölnischen Geschichtsvereins, 21, (1939), 1-46.

[51] Leguay, J. P., "Urban life", in in Jones, Michael (ed.), The new Cambridge medieval history, vol. VI: c. 1300 - c. 1415, (Cambridge, 2000), 102-25.

[52] Lindberg, E. "Club goods and inefficient institutions: why Danzig and Lubeck failed in the early modern period", The Economic History Review, (2009), 62, 604-628.

[53] Lindberg, E. "Merchant guilds in Hamburg and Konigsberg: a comparative study of urban institutions and economic development in the early-modern period", Journal of European Economic History, (Spring 2010), 39(1), 33-65.

[54] Lopez, R. S., and Raymond, I. W., Medieval Trade in the Mediterranean World: Illustrative Documents, New York, Columbia University Press, (2001).

[55] Lloyd, T. H., The English Wool Trade in the Middle Ages, Cambridge, (1977).

[56] Luchaire, A., "Philippe Auguste et son temps. 1137-1226", in Lavisse, Ernest (ed.), Histoire de France des Origines à la Révolution, (1902).

[57] Lyon, B., and Verhulst, A., Medieval Finance, (Providence, 1967). 
[58] Middleton, N. "Early medieval port customs, tolls and controls on foreign trade", Early Medieval Europe (2005), 13 (4), 313-358.

[59] Nicholas, D., The Growth of the Medieval City: From Late Antiquity to the Early Fourteenth Century, London, (1997).

[60] Ogilvie, S., Institutions and European Trade: Merchant Guilds, 1000-1800, (Cambridge University Press, 2011).

[61] Origo, I., The merchant of Prato, Francesco di Marco Datini, 1335-1410, (Boston, 1986).

[62] Ormrod, W. M., "England in the Middle Ages", in R. Bonney (ed.) The Rise of the Fiscal State in Europe c.1200-1815, Oxford, Oxford University Press, (1999).

[63] Ormrod, W. M., "England: Edward II and Edward III", in The New Cambridge Medieval History, Vol. VI: c.1300 - c. 1415, M. Jones (ed.), Cambridge, (2000), 273-96.

[64] Planitz, H., "Kaufmannsgilde und städtische Eidgenossenschaft in niederfränkischen Städten im 11. und 12. Jahrhundert", Zeitschrift der Savigny-Stiftung für Rechtsgeschichte, germanistische Abteilung, 60 (1940), 1-116.

[65] Postan, M. M., "The economic and political relations of England and the Hanse from 1400 to 1475", Medieval trade and finance, (Cambridge, 1973), 232-304.

[66] Postan, M. M., "The trade of medieval Europe: the North", in The Cambridge Economic History of Europe, Vol. 2: Trade and Industry in the Middle Ages, M. M. Postan and E. Miller (eds.), Cambridge, (1987), 168-305.

[67] Putnam, R. D., Bowling alone: the collapse and revival of American community, (New York, 2000).

[68] Putnam, R. D., Leonardi, R., and Nanetti, R. Y., Making democracy work: civic traditions in modern Italy, (Princeton, NJ, 1993).

[69] Racine, P., Les villes d'Italie: du milieu du XIIe siècle au milieu du XIVe siècle, (Paris, 2004).

[70] Racine, P., "Associations de marchands et associations de métiers en Italie de 600 à 1200 ", in Schwineköper, Berent (ed.), Gilden und Zünfte, (Sigmaringen, 1985), 127-50.

[71] Racine, P., Plaisance du Xe à la fin du XIIIe siècle: essai d'histoire urbaine, (Paris, 1979).

[72] Raiser, M., "Informal institutions, social capital and economic transition", in Cornia, Giovanni Andrea.

[73] Reyerson, K., "Commerce and communications", in Abulafia, David (ed.), The new Cambridge medieval history, vol. V: c. 1198 - c. 1300, (Cambridge, 2000), 50-70.

[74] Richardson, G. "A Tale of Two Theories: Monopolies and Craft Guilds in Medieval England and Modern Imagination", Journal of the History of Economic Thought, (2001), 23(02), $217-242$.

[75] Richardson, G., "Guilds, laws, and markets for manufactured merchandise in late-medieval England", Explorations in Economic History, (2004), 41(1), 1-25.

[76] Richardson, G., and M. McBride "Religion, longevity, and cooperation: The case of the craft guild", Journal of Economic Behavior and Organization, (2009), 71(2), 172-186. 
[77] Rotemberg, J. J., and Saloner, G., "A Supergame-Theoretic Model of Price Wars during Booms", The American Economic Review, 76, (1986), 390-407.

[78] Schofield, R., Taxation under the Early Tudors 1485-1547, (Oxford, 2004).

[79] Schultze, A., "Über Gästerecht und Gastgerichte in den deutschen Städten des Mittelalters", Historische Zeitschrift, 101, (1908), 473-528.

[80] Schulze, H. K., "Kaufmannsgilde und Stadtentstehung im mitteldeutschen Raum", in Schwineköper, Berent (ed.), Gilden und Zünfte, (Sigmaringen, 1985), 377-412.

[81] Schütt, H. F., "Gilde und Stadt", Zeitschrift der Gesellschaft für Schleswig-Holsteinische Geschichte, 105 (1980), 77-136.

[82] Seider, H. (2005) "Die Wormser Stadtverfassung im Zeitalter des Investiturstreites", University of Frankfurt Ph.D. dissertation.

[83] Smith, R. S., The Spanish guild merchant: a history of the consulado, 1250-1700, (Durham, NC, 1940).

[84] Smith, L., "Town Life", in F. P. Barnard, ed., Companion to English History (Middle Ages). London: Clarendon, (1902).

[85] Sobel, J., "Can we trust social capital?", Journal of Economic Literature, 40, (2002), 139-54.

[86] Spufford, P., "Trade in fourteenth-century Europe", in Jones, Michael (ed.), The new Cambridge medieval history, vol. VI: c. 1300 - c. 1415, (Cambridge, 2000), 155-208.

[87] Spruyt, H. The sovereign state and its competitors, (Princeton, New Jersey, 1994).

[88] Stiglitz, J., "New bridges across the chasm: institutional strategies for the transition economies" (World Bank, 8 Dec. 1999). http://wbln0018.worldbank.org/ eca/eca.nsf/.

[89] Volckart, O., and Mangels, A., "Are the roots of the modern lex mercatoria really medieval?", Southern Economic Journal, 65, (1999), 427-50.

[90] Webber, C., and Aaron, W., A History of Taxation and Expenditure in the Western World, (New York, 1986).

[91] Woodward, R. L. Jr., "Merchant guilds", in Encyclopedia of World Trade from Ancient Times to the Present, Vol. 3, C. C. Northrup (ed.), New York, (2005), 631-8.

[92] Zakharov, V.N., Harlaftis, G., and O. Katsiardi-Hering (eds.), Merchant Colonies in the Early Modern Period, Pickering \& Chatto, London, 2012. 


\section{Appendix}

Proof of Lemma 1. The proof of this result follows directly from the sign of the derivative of $\Phi(n)$. As explained in the text, $\frac{\partial \Phi(n)}{\partial n} \geq 0$ when $x \geq \bar{x}$. Hence, by $\mathbf{A} \mathbf{1}$ the self-enforceability constraint (2) always holds in this region of parameters regardless of $n$. Next, consider the case $x<\bar{x}$. In this region of parameters $\frac{\partial \Phi(n)}{\partial n}<0$. Hence, $\Phi(n) \geq 0$ if and only if

$$
(n-1)\left[\Delta+\frac{\delta}{1-\delta}(f-\alpha x)\right] \leq \frac{\delta \alpha}{1-\delta}[\Delta-x(N-1)]
$$

which yields immediately $\bar{n}$. Applying the Implicit function Theorem to $\Phi(n) \equiv 0$ it is easy to verify that

$$
\frac{\partial \bar{n}}{\partial \Delta}=\frac{\frac{\delta \alpha}{1-\delta}+1-\bar{n}}{\Delta+\frac{\delta}{1-\delta}(f-\alpha x)},
$$

where $\frac{\delta \alpha}{1-\delta}+1>\bar{n}$, otherwise $\Phi(n)<0$ for any $n$. Hence, $\frac{\partial \bar{n}}{\partial \Delta}>0$ in the region of parameters under consideration. Similarly, using $\mathbf{A 1}$, it can be shown that

$$
\begin{array}{cc}
\frac{\partial \bar{n}}{\partial \delta}=\frac{\frac{1}{\delta(1-\delta)} \Delta(\bar{n}-1)}{\Delta+\frac{\delta}{1-\delta}(f-\alpha x)}>0, & \frac{\partial \bar{n}}{\partial x}=\frac{\Delta-\bar{x}(N-1)}{(\bar{x}-x)^{2}}>0, \\
\frac{\partial \bar{n}}{\partial N}=-\frac{\frac{\alpha \delta x}{1-\delta}}{\Delta+\frac{\delta}{1-\delta}(f-\alpha x)}<0, & \frac{\partial \bar{n}}{\partial f}=-\frac{(\bar{n}-1) \frac{\delta}{1-\delta}}{\Delta+\frac{\delta}{1-\delta}(f-\alpha x)}<0,
\end{array}
$$

and that

$$
\frac{\partial \bar{n}}{\partial \alpha}=\frac{\frac{\delta}{1-\delta}[\Delta-x(N-1)]+(\bar{n}-1) \frac{\delta x}{1-\delta}}{\Delta+\frac{\delta}{1-\delta}(f-\alpha x)}>0,
$$

which completes the proof.

Proof of Proposition 2. Suppose first that $x \leq \underline{x}$. In this region of parameters the guild's objective function is decreasing in $n$ and $\frac{\partial \Phi(n)}{\partial n}<0$. Hence, the optimal density is $n^{*}=1$, which is a viable solution under A1. Next suppose that $x \in(\underline{x}, \bar{x}]$. In this region of parameters the guild's objective function is increasing in $n$ while $\frac{\partial \Phi(n)}{\partial n} \leq 0$. Hence, the optimal density is $n^{*}=\bar{n}<N$. Finally, consider the range $x>\bar{x}$. In this case the guild's objective function is increasing and $\frac{\partial \Phi(n)}{\partial n}>0$. Hence, the optimal density is $n^{*}=N$.

Proof of Proposition 3. Although in the paper we have confined attention to the case in which $n^{*}$ is interior - i.e., $x \in(\underline{x}, \bar{x})$ - for completeness here we will prove the result by considering every possible guild's size.

Suppose first that $x \leq \underline{x}$, so that $n^{*}=1$. Replacing $n^{*}=1$ into the guilds' objective function one immediately obtains

$$
W(1)=\frac{\alpha(\Delta-x(N-1))}{1-\delta} .
$$

Comparing $W(1)$ and $V^{T}$ we have

$$
W(1)>V^{T} \quad \Leftrightarrow \quad \psi \geq \psi_{0} \equiv \frac{x(N-1)}{\Delta},
$$


which by $\mathbf{A} \mathbf{1}$ is in the unit interval $(0,1)$. Notice also that $\psi_{0}$ is increasing in $x$ and $N$, and decreasing in $\Delta$.

Next suppose that $x \in(\underline{x}, \bar{x})$, so that $n^{*}=\bar{n}<N$. Replacing $n^{*}=\bar{n}$ into the guilds' objective function one immediately obtains

$$
W(\bar{n})=W(1)+\frac{(\bar{n}-1)(\alpha x-f)}{1-\delta} .
$$

Comparing $W(\bar{n})$ and $V^{T}$ we have

$$
\begin{aligned}
W(\bar{n})-V^{T} & =\frac{\alpha(\Delta-x(N-1))-(\bar{n}-1)(f-\alpha x)}{1-\delta}-\frac{\alpha \Delta(1-\psi)}{1-\delta}= \\
& =\frac{1}{1-\delta}[\alpha \Delta \psi-\alpha x(N-1)-(\bar{n}-1)(f-\alpha x)] .
\end{aligned}
$$

Note that, as long as $\psi=0$ then $W(\bar{n})<V^{T}$, while $W(\bar{n})>V^{T}$ when $\psi=1$. Hence:

$$
W(\bar{n})>V^{T} \quad \Leftrightarrow \quad \psi \geq \psi_{1} \equiv \frac{1}{\Delta}\left[x(N-1)-\frac{(\bar{n}-1)(\alpha x-f)}{\alpha}\right] \in(0,1) .
$$

Using the definition of $\bar{n}$ the threshold $\psi_{1}$ can be rewritten as

$$
\psi_{1} \equiv \psi_{0}-\frac{(\Delta-x(N-1))(\alpha x-f)}{\Delta \alpha(\bar{x}-x)} .
$$

Recalling that

$$
\bar{x} \equiv \frac{f}{\alpha}+\frac{(1-\delta) \Delta}{\alpha \delta},
$$

simple differentiation of $\psi_{1}$ implies that this threshold is increasing in $N$ and $f$, while decreasing in $\delta$ and $\alpha$. To study the impact of $\Delta$ and $x$ it is more convenient to observe that by Lemma 1 $\bar{n}$ is increasing in $\Delta$ and decreasing in $x$.

Differentiating with respect to $\Delta$

$$
\frac{\partial \psi_{1}}{\partial \Delta}=-\frac{1}{\Delta^{2}} \underbrace{\left[x(N-1)-\frac{(\bar{n}-1)(\alpha x-f)}{\alpha}\right]}_{>0}-\underbrace{\frac{\partial \bar{n}}{\partial \Delta} \frac{(\alpha x-f)}{\Delta \alpha}}_{>0},
$$

implying that $\frac{\partial \psi_{1}}{\partial \Delta}<0$.

Differentiating with respect to $x$ we have

$$
\frac{\partial \psi_{1}}{\partial x}=\underbrace{\frac{N-\bar{n}}{\Delta}}_{>0}-\underbrace{\frac{\alpha x-f}{\Delta \alpha} \frac{\partial \bar{n}}{\partial x}}_{<0},
$$

implying that $\frac{\partial \psi_{1}}{\partial x}<0$.

Finally, suppose that $x \geq \bar{x}$, so that $n^{*}=N$. Replacing $n^{*}=N$ into the guilds' objective 
function one immediately obtains

$$
W(N)=\frac{\alpha \Delta-f(N-1)}{1-\delta}
$$

Comparing $W(N)$ and $V^{T}$ we have immediately

$$
W(N) \geq V^{T} \quad \Leftrightarrow \quad \psi \geq \psi_{2} \equiv \frac{f(N-1)}{\Delta \alpha}
$$

with $\psi_{2} \in(0,1)$ by $\mathbf{A} 1$ and $\psi_{2}$ being increasing in $N$ and $f$, and decreasing in $\alpha$ and $\Delta$.

Hence, the result stated in the proposition follows immediately by setting $\psi_{1}=\psi^{*}$.

\section{Further Extensions}

Constraints on the guild density. Lemma 1 and subsequent results hinge on assumption A1 which guarantees that both a single-member guild and a guild that includes all merchants are viable. Now we argue that our qualitative insights would not change if these assumptions were relaxed.

Consider first $\Delta-x(N-1)<0$ and $\alpha \Delta-(N-1) f \geq 0$ : in this case a single monopolist is not able to prevent unauthorized trade by its $N-1$ competitors, whereas operating costs are not so high as to prevent a full-size guild. Hence, a necessary condition for a guild to be viable is $\Delta-x(N-n) \geq 0$, which implies an endogenous minimal guild density $n_{0} \equiv N-\frac{\Delta}{x}$. Recalling that

$$
\Phi(n) \equiv \frac{\delta \alpha}{1-\delta}[\Delta-x(N-1)]-(n-1)\left[\Delta+\frac{\delta}{1-\delta}(f-\alpha x)\right]
$$

it follows that a necessary condition to prevent undercutting is now $x \geq \bar{x}$. In this case $\Phi(n) \geq 0$ requires

$$
n \geq n_{1} \equiv 1+\frac{x(N-1)-\Delta}{x-\bar{x}} .
$$

The ruler has thus the option of recognizing a guild if and only if

$$
N \geq 1+\frac{x(N-1)-\Delta}{x-\bar{x}} \Leftrightarrow N \leq 1+\frac{\Delta}{\bar{x}}
$$

When this condition is met, it can be easily verified that the optimal guild size is $n^{*}=N$, so that Propositions 2 and 3 stilly apply, but only for $x \geq \bar{x}$. Otherwise, the ruler prefers the tax collector.

Next, consider $\Delta-x(N-1) \geq 0$ and $\alpha \Delta-(N-1) f<0$. This means that, in addition to the constraints stated in Lemma $\mathbf{1}$, there is an additional endogenous upper-bound to the guild density which comes from the constraint

$$
\alpha(\Delta-x(N-1))-(n-1)(f-x \alpha) \geq 0
$$

which can bind only when $x \leq \underline{x}$. However, in this region of parameters $n^{*}=1$. Hence, the results of the baseline model go through even in this case.

Finally, it is straightforward to show that when

$$
\Delta \leq(N-1) \min \left\{x, \frac{f}{\alpha}\right\}
$$


the guild solution is not viable at all. In this case the only option left to the ruler is to hire a tax collector. Even if this result did not emerge in the baseline analysis, it is still in line with the comparative statics of Proposition 3, showing that the emergence of a merchant guild is positively correlated with $\Delta$. It also highlights once more the importance of social capital for the guild solution.

Non-deterministic exclusion. We now consider how results are affected by relaxing the assumption that non-payment of exclusion costs by a single member is enough to give rise to undercutting with certainty (and hence zero guild profits). In particular, we assume instead that each member's exclusion effort increases the exclusion probability by $1 / n$, so that if all members contribute there is exclusion, but if one member shirks exclusion succeeds with probability $(n-1) / n$. As before, just for simplicity we assume that there is perfect monitoring - i.e., regardless of whether exclusion fails or not, if a merchant does not contribute to the exclusion effort in one period, the other members spot the deviation by the end of that period and either exclude him from future trade or dissolve the guild, so that his profit in the punishment phase is zero. ${ }^{76}$

An equilibrium in which active merchants quote the monopoly price and every member exerts exclusion effort can exist if and only if price deviations are not profitable - i.e., if

$$
\frac{\Delta-x(N-n)}{n}+\frac{\delta}{1-\delta}\left[\frac{\alpha(\Delta-x(N-n))-(n-1) f}{n}\right] \geq \max \left\{\Delta-\frac{x(N-n)}{n}, \frac{n-1}{n} \Delta\right\},
$$

where the right-hand side represents the highest payoff a merchant can secure by undercutting the monopoly price. In fact, while undercutting $p^{M}$ a deviating merchant can either decide to exert exclusion effort, in which case he obtains a profit of $\Delta-x(N-n) / n$, or he can refrain from contributing to exclusion, thereby taking the risk of letting outsiders enter the market with probability $1 / n$, in which case he makes zero profits. ${ }^{77}$ Note that

$$
\Delta-\frac{x(N-n)}{n} \geq \frac{n-1}{n} \Delta \quad \Leftrightarrow \quad \Delta \geq x(N-n),
$$

which must be true in order for the guild to be profitable - i.e.,

$$
\alpha(\Delta-x(N-n))-(n-1) f \geq 0 \quad \Rightarrow \quad \Delta \geq x(N-n) .
$$

Hence, when the guild is profitable, the best strategy for a deviating merchant is to undercut the monopoly profit and exert the exclusion effort - i.e.,

$$
\max \left\{\Delta-\frac{x(N-n)}{n}, \frac{n-1}{n} \Delta\right\}=\Delta-\frac{x(N-n)}{n} .
$$

This implies that the baseline analysis is still valid in an environment with a different monitoring technology, in which limited free-riding on the exclusion effort is less harmful than we assumed in the baseline model.

Imperfect collusion. Our baseline analysis for the guild regime entails perfect collusion when demand is positive - i.e., guilded merchants charge the monopoly price $p^{M}=\Delta$ if and only if $v^{\tau}=\Delta$. It is interesting, as an extension of the basic analysis, to consider circumstances

\footnotetext{
${ }^{76}$ This assumption is made only to simplify the exposition, it can be shown that nothing changes when there is perfect monitoring regarding price deviations but shirking on the exclusion effort is not observed if exclusion is successful. The proof is available upon request.

${ }^{77}$ When exclusion fails the market equilibrium is the competitive one.
} 
in which imperfect collusion may occur in equilibrium. In particular, if demand can take more than two values, it can be the case that for very high demand states the equilibrium will entail imperfect collusion - i.e., guilded merchants will charge a price below the monopoly price (albeit still above the competitive price, hence still a collusive price). The intuition for this is that for very high demand states, the spot gain from deviation may be too high to sustain the perfectly collusive outcome.

Formally, we can study this possibility by assuming that the consumer's willingness to pay, $v^{\tau}$, is determined by the realization of a continuous random variable drawn from a uniform distribution with support $[0,1]$, which is identically and independently distributed over time (see, e.g., Rotemberg and Saloner, 1986). For simplicity we abstract from explicit consideration of exclusion and coordination costs (i.e., we set $x=f=0$ ), and just assume that one-member guilds are not feasible ${ }^{78}$, so that the guild regime requires collusion.

Let $n$ (where $N \geqslant n>1$ ) be the subset of active merchants belonging to the guild. A collusive outcome is sustainable as long as it is in each merchant's best interest not to break the agreement. This requires

$$
\frac{v}{n}+\frac{\delta \mathrm{E}[v]}{(1-\delta) n} \geq v
$$

in any given state $v$. The left-hand side of this condition can be interpreted as the (discounted) gain from cooperation, while the right-hand side is the spot gain from deviation.

Rearranging equation (2), collusion can be sustained in state $v$ if and only if

$$
v \leq \frac{\delta \mathrm{E}[v]}{(n-1)(1-\delta)}
$$

Thus for sufficiently large realizations of $v$ it may not be possible to sustain full collusion i.e., the potential gain from deviation becomes too large. In this case, the collusive agreement will require merchants to set the highest possible price level compatible with the 'no cheating' condition (6) so as to mitigate the temptation to undercut. More precisely, there exists a threshold $v^{*} \leq 1$ such that: for all $v \leq v^{*}$ full collusion is viable and each merchant obtains earns $v / n$, while for $v>v^{*}$ full collusion is not sustainable and the maximal profit that a guild member can obtain is $v^{*} / n .^{79}$ The threshold $v^{*}$ is endogenously defined by (6) holding as an equality - i.e.,

$$
v^{*}=\frac{\delta \mathrm{E}[v]}{(n-1)(1-\delta)},
$$

where

$$
\mathrm{E}[v]=\int_{0}^{v^{*}} v d v+\left(1-v^{*}\right) v^{*}
$$

Hence, when demand is sufficiently high, the guild will obtain an aggregate profit $\left(v^{*}\right)$ which is lower than the monopoly level. Substituting (8) into (7) we have

$$
v^{*}=\frac{\delta}{(n-1)(1-\delta)}\left[\int_{0}^{v^{*}} v d v+\left(1-v^{*}\right) v^{*}\right]=\frac{2(1-n(1-\delta))}{\delta} .
$$

Notice that the larger is the guild density - i.e., the larger is $n$ - the lower is $v^{*}$, since each

\footnotetext{
${ }^{78}$ Historically, we have found no records of one-member merchant guilds. The smallest guild size we are aware of is $n=23$, for the fish merchants' guild in Worms (see, e.g., Seider, 2005, p. 49).

${ }^{79}$ The case where $v^{*}<1$ corresponds to instances where in order to support collusion in states higher than $v^{*}$ merchants must charge a price lower than the monopoly one. Formally, this implies that the guild total profit in each of these states is $\beta v$ with $\beta=v^{*} / v \leq 1$.
} 
merchant is tempted to deviate more often when the gain from collusion has to be shared among many. Hence, a collusive outcome can obtain as long as the guild density does not exceed the endogenous upper-bound $\bar{n}$ above which $v^{*}=0$ - i.e.,

$$
v^{*}>0 \quad \Leftrightarrow \quad n<\bar{n} \equiv \frac{1}{1-\delta},
$$

with $\bar{n}$ now being the solution with respect to $n$ of $v^{*}=0$. As a result, when $N$ is large enough some merchants will be excluded from trade.

This extension of the model is interesting for two reasons: first, because it shows that restrictions on guild membership can arise as a consequence of the need to sustain collusive outcomes when faced with high realizations of demand. Second, because it highlights a possible advantage of the guild regime from the point of view of consumers, relative to the tax collector regime: consumers would clearly be better off under the guild regime in high demand states $\left(v>v^{*}\right)$, since they would pay a price below the monopoly price. 